\title{
COLLUSION, OBSTRUCTION OF JUSTICE, AND IMPEACHMENT
}

\author{
By Ediberto Roman ${ }^{\dagger}$, Melissa Gonzalez ${ }^{\dagger}$, and Dianet Torres $^{\dagger}$
}

“Collusion is not a crime. ..”

- $\quad$ President Donald J. Trump, July 31, 2018

"It remains our position that the President's actions here, by virtue of his position as the chief law enforcement officer, could neither constitutionally nor legally constitute obstruction because that would amount to him obstructing himself. ..”

- The Trump Legal Team's Jan. 29, 2018,Confidential Memo to Special Prosecutor Robert Mueller ${ }^{2}$

$\dagger$ Ediberto Roman, Professor of Law, father of five, and martial arts practitioner. As with all my work, I dedicate this project to my children: May you grow inspired by your political leaders as I was by mine, which include Dr. Rev. Martin Luther King, Dwight D. Eisenhower, and Barack Obama. I would also like to thank my amazing research assistants Ms. Melissa Gonzalez, Dianet Torres, and Katryna Santa Cruz for their incredible work.

$\dagger$ Melissa Gonzalez, J.D. Candidate, Florida International University, Class of 2020. I would like to express my gratitude to Professor Ediberto Roman for the opportunity to assist him on this policy-making legal endeavor. I also must thank my parents for sacrificing everything for me to pursue my dreams, and believing in me more than I could ever believe in myself.

$\dagger$ Dianet Torres, J.D. Candidate, Florida International University, Class of 2020. To my mother, the light and strength of my life. You are always with me.

1 Donald J. Trump (@realDonaldTrump), TwITTER (July 31, 2018, 4:58 AM), https://twitter.com/realDonaldTrump/status/1024263146008207361.

2 Jessica Kwong, Trump Lawyers' Letter to Mueller With Comic Sans Letterhead: President Can't Obstruct Justice, Shouldn't Testify, NEwswEEK (June 2, 2018) https://www.newsweek.com/trump-lawyers-wrote-letter-comic-sans-letterhead-mueller-keep-president-955035. 


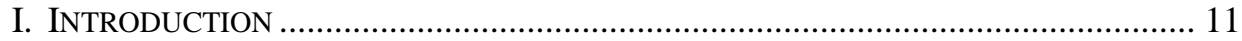

II. THE QUESTION OF COLLUSION AND OBSTRUCTION ....................................... 12

III. THE TERM COLLUSION AND ITS LEGAL GENESIS............................................... 13

IV. The History OF THE FEdERAL OfFENSE OF OBSTRUCTION OF JUSTICE .......... 17

V. The Evolution of the Omnibus Obstruction STAtute 18 U.S.C. $\S$

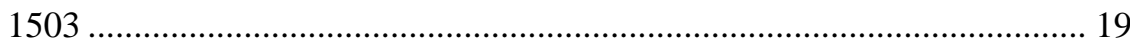

A. The Pivotal "Pending Proceeding” Requirement of Section 1503.......... 23

B. Establishing Intent Through the Natural and Probable Consequences

Doctrine....

VI. ConSPIRACy to ObSTRUCt JUSTICE UnDER SECTION 1503 ............................. 28

VII. OBSTRUCTION OF Justice Under § 1512: PROTECT WitnesSES, Victims,

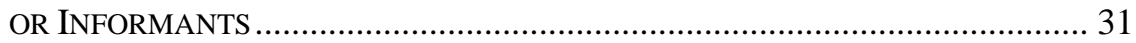

VIII. 18 U.S.C. § 1510 OBSTRUCTION OF JUSTICE BEFORE THE INITIATION OF

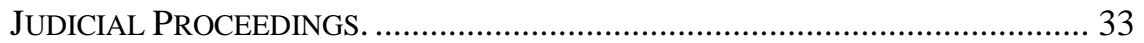

IX. IMPEACHMENT AND CRIMINAl Charges AgAinst A SitTing PrESIDENT ...... 37

X. Various Factual Allegations that May Give Rise to ObStruction

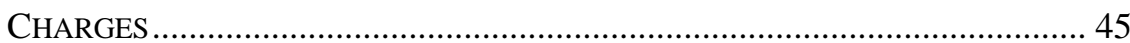

A. The Michael Flynn Investigation, the Comey-Trump Meeting, and Ultimate Comey Firing.......................................................................... 45

B. Trump Tower Meeting and Subsequent Explanation ................................ 52

XI. CONCLUSION ……………………………………......................................... 58 


\section{INTRODUCTION}

What happens to a country's reputation, which is purportedly founded on the integrity of an honest and fair justice system, when its leader is the target of an obstruction of justice investigation? Related to this, how should society react to repeated claims that the press is the enemy of the state? How should anyone feel when the prevailing ethos seems to be references to a "witch hunt" or "fake news?" Think back five years ago, did anyone think a president of the strongest country in the world would create policy and otherwise communicate via Twitter?

Combine all the emotions that ran through your head while reading those questions and apply them as you read this Article. Today, the United States of America has Donald Trump as its President, and he appears to be the target of an obstruction of justice investigation. It appears that the President is ready to insult any perceived antagonist: even if it undermines the national intelligence apparatus and belittles our federal law enforcement. Indeed, according to his detractors, President Trump cannot stop himself from brazenly interjecting and interfering with FBI investigations of illegal acts done by former Army Lieutenant General, Michael Flynn. There are also allegations that the President even worked with foreign nationals in violation of federal election proscriptions that ultimately undermined our holiest of democratic edifices - the sanctity of the vote.

Even with all the facts that have come to light since January 2017, President Donald Trump and his administration clench to the narrative that the aforementioned allegations have no merit. Yet, the House impeached President Bill Clinton, ${ }^{3}$ and was prepared to impeach Richard Nixon, before he resigned, ${ }^{4}$ for obstruction of justice, with only a fraction of the evidence that may be set forth against President Trump. In the following pages, this Article will explore the merits of recent efforts to justify the President's behavior, including the suggestion that collusion is not a crime. Ultimately, federal law provides a clear definition of collusion, even if the word itself cannot be found as a defined statutory violation. These cases provide that collusive acts are the predicate acts of a criminal wrong. In a potential impeachment of President Trump, any acts found to be collusive may become the basis for one or more obstruction of justice claims or charges. This Article also explores the federal offense of obstruction of justice. The catch-all obstruction provision of 18 U.S.C. § 1503 , is accordingly examined. After said review, three other independent legal justifications under the obstruction statutes are explored. The leading factual wrongs allegedly committed President Trump under the federal obstruction statutes are then examined. Finally, whether a sitting president may face criminal charges is examined. In the end, we conclude, if Special Prosecutor Robert Mueller decides there is a factual basis of presidential wrongdoing, and a trier of fact so agrees, federal law on obstruction of justice provides ample basis for articles of impeachment and possibly a federal indictment.

3 Approved Articles of Impeachment of William Jefferson Clinton, WASH. PosT (Dec. 20, 1998), https://www.washingtonpost.com/wp-srv/politics/special/clinton/stories/articles122098.htm.

4 Articles of Impeachment, WATERGATE.INFO. http://watergate.info/impeachment/articles-of-impeachment (Article1 of the Articles of Impeachment adopted by the House Judiciary Committee on July 27, 1974, containing an obstruction of justice charge). 


\section{THE QUESTION OF COLLUSION AND OBSTRUCTION}

The notion of impeaching a sitting United States President is envisioned in the very first iteration of the United States Constitution in Article II, Section 4, which provides: "The President, Vice President and all civil Officers of the United States, shall be removed from Office on Impeachment for, and Conviction of, Treason, Bribery, or other high Crimes and Misdemeanors." 5

In the context of President Trump's alleged wrongful acts, pundits, ${ }^{6}$ politicians, ${ }^{7}$ news outlets, ${ }^{8}$ scholars, ${ }^{9}$ and even the President ${ }^{10}$ himself have expressed their views on whether one fact tor another rise to the level of an impeachable offense. However, these commentators fail to provide the legal basis or reason why an act rises to the level of obstruction of justice and, accordingly, may provide the basis for a finding of a high crime or misdemeanor under Article II of the U.S. Constitution. As alluded to above, President Trump's purported wrongful acts range from his efforts to persuade FBI Director James Comey to end an investigation of National Security Advisor Michael Flynn. They also include the President's purported involvement in a meeting with foreign nationals who claimed to have damaging information on the President's campaign opponent. ${ }^{11}$ The thrust of the potential legal wrongs with respect to these and other related instances is whether the President, among other things, violated the federal obstruction of justice statutes. Most recently, the President, his counsel, and others have attempted to morph the question of obstruction of justice, to a question of whether the President “colluded” with Russians or the Russian government.

Despite the wealth of public discussion on the matter, there is surprisingly little discussion on the law of obstruction of justice. An overwhelming majority of speakers or guests on television and radio news stations such as CNN, ${ }^{12}$ Fox News, ${ }^{13}$ and

5 U.S. CONST. art. II, $\S 4$.

6 Bob Baur, The Impeachable Offense and the Modern Presidency, LAWFARE (Sept. 14, 2017), https://www.lawfareblog.com/impeachable-offense-and-modern-presidency.

7 Chris Cillizza, The Democratic Case Against Impeaching President Trump, CNN (Aug. 18, 2018), https://www.cnn.com/2018/04/09/politics/impeachment-trump-axelrod/index.html.

8 Keith E. Whittington, So What Exactly Counts as an Impeachable Offense?, WASH. POST (May 24, 2017), https://www.washingtonpost.com/news/monkey-cage/wp/2017/05/24/so-what-exactly-counts-as-animpeachable-offense-spoiler-its-a-trick-question/?utm_term=.12b6a85d8a75.

9 Albert Broderick, The Politics of Impeachment, 60 AM. B. Ass'N J. 5 (1974), available at https://www.jstor.org/stable/25726736?seq=1\#page_scan_tab_contents.

10 Amy Davidson Sorkin, Donald Trump, Bill Clinton, and How Presidents View Impeachment, THE NEW YORKER (June 5, 2018), https://www.newyorker.com/news/daily-comment/donald-trump-bill-clintonand-how-presidents-view-impeachment.

11 Marshall Cohen, Trump Lawyers Say He 'Dictated' Statement on Trump Tower Meeting, Contradicting Past Denials, CNN (June 2, 2018), https:/www.cnn.com/2018/06/02/politics/trump-lawyers-statementtrump-tower-russians/index.html; Betsy Woodruff, White House Lawyers Say Trump Wrote Misleading Response to Trump Tower Meeting, THE DAILY BEAST (June 2, 2018), https://www.thedailybeast.com/trumpsown-lawyers-say-trump-wrote-white-house-response-to-trump-tower-meeting.

12 Deval Patrick, I Support Impeaching President Trump if..., CNN (Aug. 5, 2018), https://www.cnn.com/videos/politics/2018/08/05/deval-patrick-trump-impeachment-sotu-vpx.cnn.

13 Bob Barr, Trump is Headed for Impeachment if Republicans Don't do These Things to Hold the 
MSNBC, ${ }^{14}$ to virtually every congressional leader, ${ }^{15}$ and even political candidates, ${ }^{16}$ have opined on what they believe is tantamount to obstruction of justice in the context of the current investigation. What adds to the lack of clarity on the matter, the President and his attorney, Rudy Giuliani, have used the term "collusion" as the basis for any alleged wrongful act on his part. ${ }^{17}$ Astonishingly, they even have gone as far as to assert that collusion is not a crime. ${ }^{18}$ Sadly, even legal experts invited to these programs have discussed the terms collusion and obstruction but again have failed to provide any depth or details, let alone law in their analyses. That dearth of informed discussion on the law of obstruction of justice ends here. Specifically, this Article will explore the law of obstruction of justice, from its genesis, to the early federal cases defining the term, to its applicability to this president, and finally, this Article will address whether there are any potentially successful arguments applicable to an obstruction claim against the forty-fifth President of the United States. Before an indepth discussion on obstruction of justice and the federal statutes governing this type of offense, an analysis of the apparent red herring that is the claim that "collusion is not a crime" will be addressed. The legal analysis of the term collusion is explored and ultimately dismissed as a basis to suggest no wrongdoing occurred in President Trump's case.

\section{THE TERM COLLUSION AND ITS LEGAL GENESIS}

The legal term "collusion" is primarily used in the context of antitrust law, specifically under The Sherman Act, the leading federal antitrust statute. ${ }^{19}$ The purpose

House, Fox News (June 13, 2018), http://www.foxnews.com/opinion/2018/06/13/trump-is-headed-for-impeachment-if-republicans-dont-do-these-things-to-hold-house.html.

14 Maxine Waters, On Impeachment: We Can't Wait for 2020, MSNBC (Mar. 23, 2018), https://www.msnbc.com/all-in/watch/maxine-waters-on-impeachment-we-can-t-wait-for-20201193893443537.

15 Kaitlyn Schallhorn, Democratic Congressman Pushes to Impeach Trump: What to Know About the Process, Fox News (May 15, 2018), http://www.foxnews.com/politics/2018/05/15/democrat-congressmanpushes-to-impeach-trump-what-to-know-about-process.html.

16 Ian Schwartz, Tom Steyer: Trump "Has Met the Boundaries for Impeachment," American People in "Great Danger", REAL ClEAR POLITICS (Oct. 28, 2017), https://www.realclearpolitics.com/video/2017/10/28/tom_steyer_trump_has_met_the_boundaries_for_impeachment_american_people_in_great_danger.html.

17 William Cummings, Giuliani and Trump 'misleading' When They Say Collusion is Not a Crime, Law Professor Says, USA TODAY (July 31, 2018), https://www.usatoday.com/story/news/politics/2018/07/31/collusion-donald-trump-giuliani-legal-definition/873358002/; David Graham, Scandalous Beyond a Reasonable Doubt,, THE ATLANTIC (July 31, 2018), https://www.theatlantic.com/politics/archive/2018/07/trump-collusion-not-a-crime/566417/; Brian Williams, Giuliani Says Collusion's Not a Crime. But That Might Not Matter., MSNBC (July 30, 2018), https://www.msnbc.com/brian-williams/watch/giulianisays-collusion-s-not-a-crime-but-that-might-not-matter-1288822851876.

18 Id.

1915 U.S.C. § 1 (2004). ("Every contract, combination in the form of trust or otherwise, or conspiracy, in restraint of trade or commerce among the several States, or with foreign nations, is declared to be illegal.”); see also Oliver Black, CONCEPTUAl Foundations of ANTITRUst, 164-66 (2005) (Both forms of coordination violate Section 1). Compare United States v. Socony-Vacuum Oil Co., 310 U.S. 150, 224 n.59 (1940) (holding “a conspiracy to fix prices violates $\S 1$. . though no overt act is shown ....”), with United States v. U.S. Steel Corp., 223 F. 55, 159 (D.N.J. 1915), aff'd, 251 U.S. 417, 460 (1920). 
of the Sherman Act, and antitrust law in general, is to prevent wrongful monopolization and restraint of trade. ${ }^{20}$ In that context, collusion is associated with a contract or combination, otherwise known as a concerted action, to obtain something forbidden under the law. ${ }^{21}$ The theory of concerted action has become central to finding cartellike behavior, which is viewed as critical to antitrust policy. ${ }^{22}$ The term collusion in the antitrust context is defined as an agreement, contract, combination, or conspiracy to engage in price fixing, bid rigging, or market division of allocation for goods or services. ${ }^{23}$ In Tomiyosu v. Golden, ${ }^{24}$ the Nevada Supreme Court provided a useful definition that, although arising in an antitrust case, was general enough to provide guidance in a host of contexts, including impeachment. The Tomiyosu court found collusion to be:

[a]n agreement between two or more persons to defraud a person of rights by the forms of law, or to obtain an object forbidden by law. ${ }^{25}$

Federal courts as well as the Department of Justice recognize that collusion in the antitrust setting is a wrong - a view followed by courts in a host of other settings. It entails an agreement or understanding by two or more persons to obtain a result that is otherwise forbidden by the law. Federal courts have repeatedly recognized the basic notion that collusion involves an undertaking to circumvent the requirements or mandates of the law. Dating back as far as 1900, the United States Supreme Court, ${ }^{26}$ observed that "collusion" is "an agreement between two or more persons to defraud a person of his rights by the forms of law, or to obtain an object forbidden by law." 27 More recently, the Fifth Circuit Court of Appeals, in National Union Fire Ins. Co. of Pittsburgh, Pa. v. Cagle, ${ }^{28}$ provides further guidance when it cited with approval the following definition and also found at least three means to find collusion:

20 See, e.g., Standard Oil Co. v. United States, 221 U.S. 1, 50 (1911); Parker v. Brown, 317 U.S. 341, 351 (1943); Hans B Thorelli, The Federal ANTitrust Policy: Origination of AN AMERICAN Tradition 108-59, 227 (1955); ABA Antitrust Section, Monograph No. 4, The Robinson-Patman Act: Policy AND LAW Volume 1-4 (1980); Richard Posner, ANTITRUST LAW 23 (1976); EARL W. KinTNER, THE LEGISLATIVE History Of THE FEDERAl ANTITRust LaWs AND RELATED StatuTES 10-12, 30 (1978); Julian O. Von KalinowsKi, ANTitrust Laws AND TRAde Regulation, 23 (1983); E. Kintner, Federal Antitrust Law 129 (1980); Franklin D. Jones, Historical Developments Of The Law Of Business Competition, 36 Yale L.J. 207, 218 (1926).

21 Supra note 19.

22 William H. Page, Objective and Subjective Theories of Concerted Action, 79 ANTITRUST L.J. 215 (2013).

23 Id.; see also Marucci Sports, L.L.C. v. National Collegiate Athletic Ass’n, 751 F3d 268 (5th Cir. 2014) ("To satisfy the conspiracy element of a Sherman Act claim, Marucci must show "that the defendants engaged in concerted action, defined as having 'a conscious commitment to a common scheme designed to achieve an unlawful objective.”') (emphasis supplied).

24 Tomiyosu v. Golden, 400 P2d 415, 417 (1965), cert. denied, Haluska v. Gardner, 382 U.S. 844 (1965).

25 Id. at 417.

26 Dickerman v. Northern Trust Co., 176 U.S. 181, 190 (1900).

27 Id.

2868 F.3d 905 (5th Cir. 1995). 
(1) A deceitful agreement between two or more persons, for one party to bring an action against the other for some evil purpose, such as to defraud a third party of its rights;

(2) A secret arrangement between two or more persons, whose interests are apparently conflicting, to make use of the forms and proceedings of law in order to defraud a third party or to obtain that which justice would not give them, by deceiving a court or its officers; or

(3) A secret combination, conspiracy or concert of action between two or more persons for fraudulent or deceitful purposes.

Central to the federal cases defining the term collusion is the recognition that a collusive act arises when one is engaging in behavior that seeks to circumvent the law. It is that goal and intent that makes the act of colluding a wrong. A federal court in UAW v. General Motors Corp., ${ }^{29}$ put it nicely when it found collusion to be:

"[a]n agreement between two or more persons to defraud a person of his rights by the forms of law, or to obtain an object forbidden by law. It implies the existence of fraud of some kind, the employment of fraudulent means, or of lawful means for the accomplishment of an unlawful purpose. A secret combination, conspiracy or concert of action between two or more persons for fraudulent or deceitful purpose.”30

The U.S. Department of Justice and the Federal Trade Commission observed, in a mergers and acquisitions setting, "[t]he phrase 'coordinated interaction' has been substituted for 'collusion' and is defined as 'actions by a group of firms that are profitable for each of them only as the result of the accommodating reactions of others.' The 'coordinated interaction' analysis boils down to whether or not the merged company could either tacitly or overtly orchestrate anti-competitive conduct among a group of competitors." ${ }^{31}$ Similarly, one scholar observed that "[c]ollusion is cooperation between two parties that should instead be competing, or at least maintaining an arm's length. By cooperating, they seek to divvy up benefits between them, excluding other parties that might otherwise claim some of the benefits. In other words, collusion is an arrangement between two or more parties designed to achieve an improper purpose, including influencing improperly the actions of another party." 32

In the context of settling cases, for instance, scholars have similarly defined "collusion" to require a secret, unethical agreement between two parties to a suit. ${ }^{33}$ In

292006 WL 334283 (E. D. Mich. 2006).

30 Id. at 3.

31 Simon M. Lorne \& Joy Marlene Bryan, The 1992 Horizontal Merger Guidelines and The 1997 Revisions, 11A ACQUISITIONS \& MERGERS § 7:12 Westlaw (database updated 2018).

32 J. Welby Leaman, It's Not Always Nice To Play Nice: Collusion, Competition, and Development, 20 PAC. MCGEorge Global Bus. \& Dev. L.J. 289, 290-91 (2007).

33 John C. Coffee, Jr., Class Wars: The Dilemma of the Mass Tort Class Action, 95 Colum. L. Rev. 1343, 1367 (1995); Martin H. Redish \& Andrianna D. Kastanek, Settlement Class Actions, the Case-or-Controversy Requirement, and the Nature of Adjudicatory Process, 73 U. CHI. L. REV. 545 (2006). 
the bankruptcy context, the Second Circuit found collusion to be "secret cooperation for a fraudulent or deceitful purpose." ${ }^{34}$ In the context of protective orders and aider and abettor liability, one scholar similarly observed: The term "collusion" is defined as an "agreement between two or more persons to defraud a person of his rights by the forms of law, or to obtain an object forbidden by law." 35 In the insurance context, collusion has been defined using plain language from a dictionary: "Webster's defines ‘collusion' as: "a secret agreement or cooperation esp. for an illegal or deceitful purpose." 36

Accordingly, the federal court decisions considering the issue all agree on the nature of the wrong that is collusion. For instance, in Adair State Bank v. American Casualty Co., the Tenth Circuit, approved the district court's specific reliance upon this definition from Black's Law Dictionary. ${ }^{37}$ In a mass tort context, the court found collusion as:

An agreement between two or more persons to defraud a person of his rights by the forms of law, or to obtain an object forbidden by law. It implies the existence of fraud of some kind, the employment of fraudulent means, or of lawful means for the accomplishment of an unlawful purpose. A secret combination, conspiracy or concert of action between two or more persons for fraudulent or deceitful purpose. ${ }^{38}$

Therefore, it is simply incorrect to assert as a defense to a potential impeachable act that "collusion is not a crime." ${ }^{39}$ In truth, it is not only a sophomoric legal ploy to suggest collusion is not a crime, but also ignorant and befuddling for any lawyer, let alone Rudy Giuliani, the President's purported lead attorney, to suggest a defense to a potential obstruction of justice claim that collusion is not a crime. Such silly ploys are akin to arguing that one who steals a car by towing it away has not committed a crime because the statute in question does not refer to stealing that type of car in that manner. Accordingly, while claiming collusion is not a crime may be a useful tool to deflect from the true legal issues relating to this investigation, such tactics must fail under a dispassionate analysis of the law.

As mentioned above, collusive acts are the factual basis of the sanctionable behavior, or legal wrong, and if the wrong is defined as a criminal act-in the context of the president - they may very well be considered to rise to the level of a high crime or misdemeanor under Article II of the U.S. Constitution. As the above cases make clear, collusive acts are wrongful and may provide the factual predicate to criminal

34 In re New York Trap Rock Corp., 42 F.3d 747, 752 (2d Cir. 1994) (quoting WeBSTER's THIRD NEW INT'L DiCTIONARY 496 (G\&C Merriam Co. 1976)).

35 Giles T. Cohen, Protective Orders, Property Interests and Prior Restraints: Can the Courts Prevent Media Nonparties From Publishing Court-Protected Discovery Materials, 144 U. PA. L. REV. 2463, 2501 (1996).

36 Michael Keeley\& Christopher A. Nelson, Critical Issues in Determining Employee Dishonesty Coverage, 44 TORT TRIAL \& INS. PRAC. L.J. 933, 981 (2009).

37 Id.

38 Sofia Adrogué, Mass Tort Class Actions in the New Millennium, 17 REV. LiTIG. 427, 456 (1998).

39 Avery Anapol, Gulliani: Collusion Is Not a Crime, The HiLl, (July 30, 2018), https://thehill.com/homenews/administration/399461-giuliani-collusion-is-not-a-crime. 
or other punishment. In the case of President Trump, much of the alleged wrongful acts turn on whether his conduct in several instances rose to the level of obstruction of justice, among other potential criminal acts. ${ }^{40}$ In particular, questions will continue to be debated regarding whether President Trump attempted to thwart the due and proper administration of justice. There are several potential claims that, if proven, could rise to impeachable offenses. First, is whether President Trump obstructed justice by requesting FBI Director James Comey to end his investigation of Michael Flynn, the National Security advisor. ${ }^{41}$ Flynn has subsequently pled guilty to several offenses, and is currently cooperating with the FBI and the Justice Department. ${ }^{42}$ Another potential factual basis is whether President Trump knew of, approved, or was otherwise involved in a meeting, known as the Trump Tower meeting, between his son, Donald Jr., and Russian nationals. The Russian nationals had links to the Russian government, which purportedly had incriminating evidence on 2016 presidential candidate Hillary Clinton. ${ }^{43}$ The question will likely turn on whether these, as well as several other acts, rise to the level of obstruction of justice, and accordingly provide the basis for impeachment. Before an analysis of the facts that may give rise to an impeachment, it is necessary to understand the applicable law of obstruction of justice.

\section{THE History of THE FEDERAL OfFENSE OF OBSTRUCTION OF JUSTICE}

The birthplace of the offense of obstruction of justice is the Declaration of Independence. ${ }^{44}$ Before the current federal statutes on the matter, and their statutory antecedents, legislatures feared the abuse of unilateral contempt power exercised by the King of Great Britain. ${ }^{45}$ Historically, obstruction of justice and contempt of court were closely related offenses. Today, the former may be punished as the latter when it occurs in the court. ${ }^{46}$ However, since 1831, "following a period of political acrimony fueled by a perceived overextension of judges' power," federal laws attempted to reduce the scope of a contempt of court charge by creating a separate criminal offense for the obstruction of justice. ${ }^{47}$

40 Though there may very well be other criminal charges that Special Prosecutor Mueller may conclude to rise to the level of impeachable acts, the focus of this Article is on obstruction of justice and whether President Trump's acts, often acting with others, rise to the level of high crimes and misdemeanors under Article II of the U.S. Constitution.

41 Stephen Collinson et. al, James Comey Testimony: Trump Asked Me to Let Flynn Investigation Go, CNN (June 8, 2017), https://www.cnn.com/2017/06/07/politics/james-comey-testimony-released/index.html

42 David S. Cloud, Flynn Confirms Cooperation with Special Counsel, Says He Wants to 'Set Things Right'., L.A. TIMES (Dec. 1, 2017), http://www.latimes.com/politics/washington/la-na-pol-essential-washington-updates-flynn-confirms-cooperation-with-special-1512146966-htmlstory.html

43 Marshall Cohen, Trump Lawyers Say He 'dictated' Statement on Trump Tower Meeting, Contradicting Past Denials, CNN (June 8, 2018), https://www.cnn.com/2018/06/02/politics/trump-lawyers-statementtrump-tower-russians/index.html

44 Daniel A. Shtob, Corruption of a Term: The Problematic Nature of 18 U.S.C. 1512(c), the New Federal Obstruction of Justice Provision, 57 VAND. L. REV. 1429, 1434-35 (2004).

45 Id. at 1435.

46 Criminal Venue in the Federal Courts: The Obstruction of Justice Puzzle., Note, 82 Mich. L. Rev. 90, 96-7 (1983).

47 Shtob, supra note 44, at 1435. 
Following its independence from England and the perceived abuse of authoritarian power, the U.S. Congress passed a law clarifying the contempt power. ${ }^{48}$ Act of March 2, 1831, the predecessor to the contemporary omnibus contempt statute: $\S$ 1503 , limited punishment to conduct in the presence of the court that obstructed the administration of justice. ${ }^{49}$ Rather than allowing the court to punish all acts of contempt of its authority wherever they may occur, Congress focused only on persons who "corruptly, or by threats or force, endeavor to influence, intimidate, or impede any juror, witness, or officer, in any Court of the United States." 50

Obstruction of justice is now recognized as meaning any "interference with the orderly administration of law and justice." 51 In a general sense, this phrase can also encompass any offense affecting government functions, such as treason, perjury, contempt, and bribery. ${ }^{52}$ According to author Stuart P. Green, obstruction of justice offenses "involve a complex web of harms to individual litigants, witnesses, jurors, and court officials, as well as to the judicial, law enforcement, and legislative systems more generally." 53 Additionally, engaging in conduct that obstructs justice significantly harms the judicial system and society in general. ${ }^{54}$ As David S. Rudstein puts it: "[b]y intentionally misleading the court, or otherwise perverting the course of justice. . . an individual deliberately destroys a fundamental objective of the justice system: to conduct an untainted trial." 55

To deter potential obstruction of justice and its repercussion in the judicial system, the United States has, throughout its history, enacted laws punishing obstructive conduct. Most recently, the federal government enacted §§ 1501-1520 of Title 18 in the United States Code to outlaw obstruction of justice. ${ }^{56}$ "The federal obstruction of justice statute is one of a series of federal criminal laws designed to safeguard the integrity of the criminal justice system and of the investigative functions of legislatures and administrative agencies." ${ }^{57}$ Section 1503, known as the catch-all provision, prohibits obstruction of justice, jury tampering, or any attempts to use force, threats, or coercion to [endeavor to] influence, obstruct, or impede the due administration of justice. $^{58}$ Related sections include $\S \S 1505,1510$, and 1512, which prohibit the obstruction of proceedings before departments, agencies, and committees, the obstruction of criminal investigations, and tampering with a witness, victim, or informant. ${ }^{59}$

To better understand obstruction of justice, particularly in the context of the

4821 Cong. CH. 99, Mar. 2, 1831, 4 Stat. 487.

49 Id.

50 Id.

51 Matthew Harrington et al., Obstruction of Justice, 51 AM. CRIM. L. REV. 1477, 1478 (2015).

52 John F. Decker, The Varying Parameters of Obstruction of Justice in American Criminal Law, 65 LA. L. REV. 49, 52 (2004).

53 Stuart P. Green, Uncovering the Cover-Up Crimes, 42 AM. CRIM. L. ReV. 9, 13 (2005).

54 Id.

55 David S. Rudstein, Retrying the Acquitted in England Part II: The Exception to the Rule Against Double Jeopardy for "Tainted Acquittals", 9 SAN DIEGO INT'L L.J. 217, 262 (2008).

56 Decker, supra note 52, at 53.

57 Joseph V. De Marco, A Funny Thing Happened on The Way to The Courthouse: Mens Rea, Document Destruction, And The Federal Obstruction Of Justice Statute, 67 N.Y.U. L. REV. 570, 571-72 (1992).

58 Obstruction of Justice, 18 U.S.C. § 1503 (1931).

59 See id. at § 1505, 1510, 1512. 
Trump investigation, this Article will first address how Congress established obstruction of justice as a crime through the Act of March 2, 1831, and its evolution into 18 U.S.C. § 1503. Next, this Article will address Congress's enactment of 18 U.S.C. § 1510 to prohibit obstruction of justice before the initiation of judicial proceedings. Then this Article will address how Congress expanded the measures against obstruction of justice when it enacted $\S 1512$ to expand the protections granted to witnesses, victims, and informants.

\section{The EVOlution OF the OMNiBus OBSTRUCTION STATUTE 18 U.S.C. § 1503}

"Whoever . . corruptly or by threats of force, or by any threatening letter or communication, influences, obstructs, or impedes, or endeavors to influence, obstruct, or impede, the due administration of justice, shall be punished . . . " 60

Congress first established the contempt power by passing the Judiciary Act of 1789, but the Act failed to define contempt. ${ }^{61}$ The initial distinction of obstruction of justice from contempt of court arose out of a controversy surrounding Judge James H. Peck. ${ }^{62}$ In 1830, Judge James H. Peck was impeached by the House of Representatives and tried by the Senate for abusing his contempt power when he held Luke Edward Lawless in contempt for publishing a letter criticizing one of Peck's opinions. ${ }^{63}$ "The extensive arguments in the Peck trial repeatedly emphasized that the contempt power should be limited to that necessary for the preservation of judicial functions." 64 After determining that the contempt power was too easily employed and potentially detrimental to procedural safeguards, Congress passed the Act of March 2, 1831, to limit the scope and contempt power of the Act of $1789 .{ }^{65}$ The Act of March 2, 1831, the predecessor to $\S 1503$, limited punishment to conduct that obstructed the administration of justice in the presence of the court. ${ }^{66}$ Rather than allowing the court to punish all acts of contempt wherever they may occur, Congress focused only on persons who "corruptly, or by threats or force, endeavor to influence, intimidate, or impede any juror, witness, or officer, in any Court of the United States." 67 The Act established obstruction of justice as a separate crime from contempt and required that those accused of the offense be charged by indictment and tried by a jury. ${ }^{6}$

Furthermore, in enacting the Act of March 2, 1831, Congress created a divide between conduct taking place in or near the court, and conduct outside the court: ${ }^{9}$

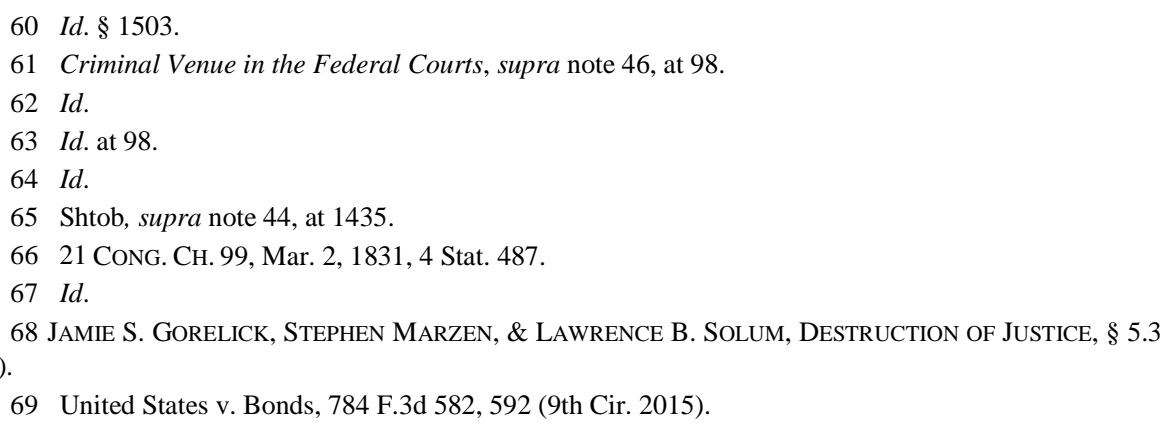


[M]isbehavior of any person or persons in the presence of said courts, or so near thereto as to obstruct the administration of justice" constituted contempt under section 1 of the Act of March 2, 1831, whereas persons outside of court who "corruptly, or by threats of force, obstruct, or impede, or endeavor to obstruct or impede, the due administration of justice" committed the crime of obstruction of justice under section $2 .{ }^{70}$

The Supreme Court differentiated in court versus out of court wrongful conduct in the Nye $v$. United States, where a majority reversed a district court's judgment convicting the petitioner for contempt of court. ${ }^{71}$ The Court reversed the conviction because the petitioner's misbehavior had occurred 100 miles away from the location of the district court in which the action was brought, and thus was not considered in the "presence" of the court nor "near thereto."72 The Court reasoned that "near thereto' referred to a geographical proximity to the court and not a proximity in casual relationship. ${ }^{73}$ The Court explained that $\S 2$ of the Act of March 2, 1831 expressly includes actions that can interfere with the administration of justice but do not take place in or near the court. ${ }^{74}$ Therefore, the Court must maintain a meticulous regard for the separate categories of offenses, "so that the instances where there is no right to jury trial will be narrowly restricted."75 Lastly, the Court explains that the two sections of the Act must be read together, and as a result "the category of criminal cases which could be tried without a jury was narrowly confined."76 The Congressional purpose behind the Act of 1831 was not only to limit the contempt power of the Court, but also to prevent summary punishments that violate the "procedural safeguards of the Bill of Rights."77

As a result, Congress successfully limited the abuse of contempt power and established the crime of obstruction of justice through the Act of March 2, 1831. This act has been codified into two separate pieces. ${ }^{78}$ Section 1 of the Act survives today as 18 U.S.C. $\S 401$, the contempt statute, while $\S 2$ survived through 18 U.S.C. $\S$ $1503 .{ }^{79}$ Courts have reasoned that obstruction of justice is to be applied to conduct

70 Id.; 21 Cong. CH. 99, Mar. 2, 1831, 4 Stat. 487.

71 Nye v. United States, 313 U.S. 33, 52, (1941)

72 Id. at $40,52$.

73 Id. at 54 .

74 Id. at 49.

75 Id.

76 Id. at 47 .

77 Cammer v. United States, 350 U.S. 399, 404, (1956).

78 United States v. Bonds, 784 F.3d 582, 592 (9th Cir. 2015).

7918 U.S.C. § 1503 (“Influencing or injuring officer or juror generally (a) Whoever corruptly, or by threats or force, or by any threatening letter or communication, endeavors to influence, intimidate, or impede any grand or petit juror, or officer in or of any court of the United States, or officer who may be serving at any examination or other proceeding before any United States magistrate judge or other committing magistrate, in the discharge of his duty, or injures any such grand or petit juror in his person or property on account of any verdict or indictment assented to by him, or on account of his being or having been such juror, or injures any such officer, magistrate judge, or other committing magistrate in his person or property on account of the performance of his official duties, or corruptly or by threats or force, or by any threatening letter or communication, influences, obstructs, or impedes, or endeavors to influence, obstruct, or impede, the due administration of justice, shall be punished as provided in subsection (b). If the offense under this section occurs in connection with a trial of a criminal case, and the act in violation of this section involves the threat of physical force or physical 
outside the court's proceedings because such was the intent of Congress, ${ }^{80}$ and that interpretation is compatible with other statutes. ${ }^{81}$ For instance, under 18 U.S.C. $\S \S$ 1621 and 1623, "a false statement made during in-court testimony constitutes perjury.” 82 Additionally, under 18 U.S.C. § 401, a refusal to answer a material question during in-court testimony constitutes contempt. ${ }^{83}$

In terms of the overall structure of the obstruction provisions, §§ 1501 through 1520 of Title 18 in the United States Code reflect the various types of outlawed behavior. As Professor Decker in his leading work on the provisions' structure observes, the individual sections identify a host of acts giving rise to criminal offenses, including: "assault on a process server," 84 "resistance to extradition agent," 85 "influencing or injuring officer or juror generally," 86 "influencing juror by writing," 87 "obstruction of proceedings before departments, agencies, and committees," 88 "theft or alteration of records or process; false bail," 89 "picketing or parading," 90 "recording, listening to, or observing proceedings of grand or petit juries while deliberating or voting," 91 "obstruction of court orders," 92 "obstruction of criminal investigations,"93 “obstruction of State or local law enforcement," 94 "tampering with a witness, victim, or an informant," 95 "retaliating against a witness, victim, or an informant,"96 "obstruction of Federal audit,"97 "obstructing examination of financial institution," 98 "obstruction of criminal investigations of health care offenses," 99 "de-

force, the maximum term of imprisonment which may be imposed for the offense shall be the higher of that otherwise provided by law or the maximum term that could have been imposed for any offense charged in such case. (b) The punishment for an offense under this section is (1) in the case of a killing, the punishment provided in sections 1111 and 1112 [18 USCS §§ 1111 and 1112]; (2) in the case of an attempted killing, or a case in which the offense was committed against a petit juror and in which a class A or B felony was charged, imprisonment for not more than 20 years, a fine under this title, or both; and (3) in any other case, imprisonment for not more than 10 years, a fine under this title, or both.”).

80 Id. at 592 (quoting Nye, 313 U.S. at 50, "[w]e cannot by process of interpretation obliterate the distinctions which Congress drew.”).

81 Bonds, 784 F.3d at 592.

82 Id.

83 Id. at 193; see also 18 U.S.C. § 401(1) (stating that a court of the United States has the power to punish the "misbehavior of any person in its presence or so near thereto as to obstruct the administration of justice”).

8418 U.S.C.A. § 1501 (West 2000 \& Supp. 2003).

8518 U.S.C. $\S 1502(2000)$.

86 Id. § 1503.

87 Id. § 1504.

88 Id. § 1505.

89 Id. § 1506.

90 Id. § 1507.

91 Id. § 1508.

92 Id. § 1509.

93 Id. § 1510.

9418 U.S.C.A. § 1511 (West 2000 \& Supp. 2003).

95 Id. § 1512.

96 Id. § 1513.

97 Id. § 1516.

9818 U.S.C.A. § 1517 (2000).

99 Id. § 1518. 
struction, alteration, or falsification of records in Federal investigations and bankruptcy," ${ }^{100}$ and "destruction of corporate audit records." ${ }^{101}$ Beyond the above provisions are two other sections, one which reflects a civil action measure ${ }^{102}$ and another that sets out basic definitions. ${ }^{103}$

Section 1503, the omnibus obstruction provision, also applies to a broad range of conduct, and thus giving rise to its broad and global name. The provision states as follows:

Whoever corruptly, or by threats or force, or by any threatening letter or communication, endeavors to influence, intimidate, or impede any grand or petit juror, or officer in or of any court of the United States, or officer who may be serving at any examination or other proceeding before any United States magistrate judge or other committing magistrate, in the discharge of his duty, . . . or corruptly or by threats or force, or by any threatening letter or communication, influences, obstructs, or impedes, or endeavors to influence, obstruct, or impede, the due administration of justice, shall be punished as provided in subsection (b). ${ }^{104}$

After the Act of March of 1831, created the obstruction of justice as a separate crime, 18 U.S.C. $\$ 1503$ has continued to address the same behaviors as its predecessor. Section 1503, which governs obstruction of justice affecting jurors, officers of the court, and judges, is considered a catch-all provision that applies to a broad range of conduct. ${ }^{105}$ Its main purpose is to protect jurors and judicial officers from threats, intimidation, retaliation, and other miscellaneous corrupt conduct. ${ }^{106}$ The broad coverage of $\S 1503$, statute stems from the use of what is called the Omnibus Clause: "corruptly endeavor[ing] to influence, obstruct, and impede the ... grand jury investigation." 107 The goal of including this clause in the provision was to "ensure that criminals [cannot] circumvent the law's purpose by devising novel and creative schemes that would interfere with the administration of justice but would nonetheless fall outside the scope of $\S 1503$ 's specific prohibitions." 108 Due to its general nature, courts referred to $\S 1503$ (a) as a catch-all provision. ${ }^{109}$ Although the provision is broad in nature, courts generally consider that the word “corruptly,” used in § 1503, means that a corruptive motiv

e caused the act, or, in other words, the purpose of the act was to obstruct justice. ${ }^{110}$ If $\S 1503$ is interpreted as applying to in-court obstruction of the administration of justice, it would be duplicative and even superfluous due to overlap with other

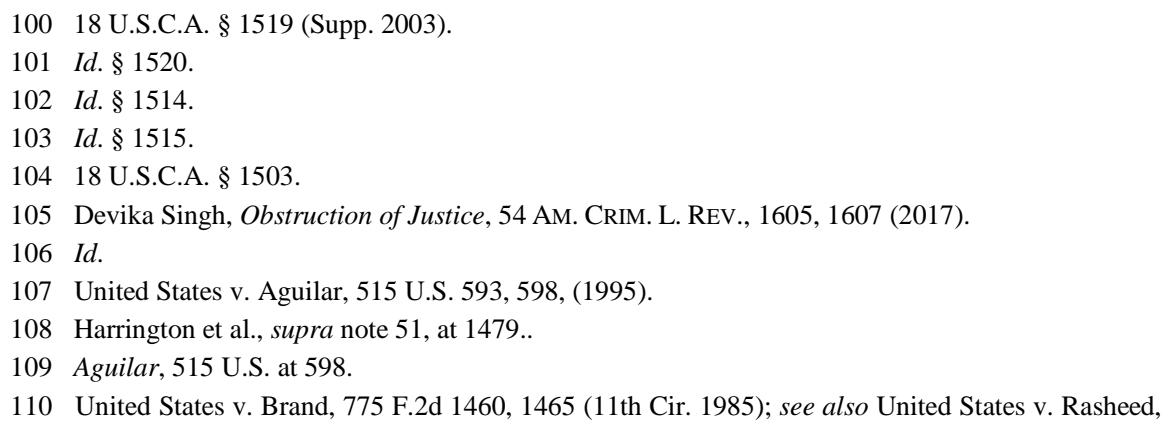


statutes. ${ }^{111}$

To prove a violation of $\S 1503$, the government must establish: (1) there is a pending judicial proceeding; ${ }^{112}$ (2) the defendant had knowledge or notice of the said proceeding; ${ }^{113}$ and (3) the defendant acted or attempted to act corruptly with the intent of influencing, obstructing, or impeding the proceeding in the due administration of justice. ${ }^{114}$ If the government establishes the prima facie case of obstruction of justice, there are only a few potentially successful defenses. ${ }^{115}$ Only two defenses to $\S 1503$ have had mild success. ${ }^{116}$ The effective defenses are an expired statute of limitations, and fear of reprisal when related to testimony in front of a jury. ${ }^{117}$ In contrast, even constitutional challenges "based on vagueness, overbreadth, and insufficient notice have failed.”118

\section{A. The Pivotal "Pending Proceeding" Requirement of Section 1503}

Particularly, in the context of the special prosecutor's investigation of President Trump, § 1503's requirement of a "pending proceeding” may very well be an issue of great debate and considerable court and perhaps congressional filings. Trump's legal team and supporters_will likely argue that the purported acts in question occurred well before a grand jury was empaneled or other judicial proceeding was underway. According to this line of thought, § 1503's pendency requirement was therefore not met. In United States v. Aguilar, the U.S. Supreme Court held that, in order to constitute a violation of $\S 1503$, a defendant's conduct must have some "nexus"i.e., some "relationship in time, causation, or logic" - to a judicial proceeding, so that the false statements have the "natural and probable effect" of interfering with that judicial proceeding. ${ }^{119}$ In terms of determining when a pending proceeding is present, Professor Decker found that federal courts have often refrained from developing a "rigid rule" to determine at what point a judicial proceeding becomes pending. ${ }^{120}$ Other scholars, arguably taking a more regimented view, conclude that " $\S$ 1503 does not give authority to prosecute obstruction of an independent government

663 F.2d 843, 852 (9th Cir. 1981); United States v. Ogle, 613 F.2d 233, 238 (10th Cir. 1979), cert. denied, 449 U.S. 825, (1980); United States v. Haas, 583 F.2d 216, 220 (5th Cir. 1978), cert. denied, 440 U.S. 981, (1979). 111 Id. at 193.

112 United States v. Mullins, 22 F.3d 1365, 1370 (6th Cir. 1994) (holding that in order to convict someone of violating $\S 1503$, the government must prove that there was a judicial proceeding underway); see also Pettibone v. United States, 148 U.S. 197, 207 (1893) (construing predecessor statute to § 1503).

113 Singh, supra note 105, at 1609; see also United States v. Williams, 874 F.2d 968, 977 (5th Cir. 1989) (delineating the elements of $\S 1503$ as having “three core elements”).

114 See Singh supra note 105.

115 Id. at 1618.

116 Id. at 1620.

117 Id.; see e.g. United States v. Banks, 942 F.2d 1576, 1579 (11th Cir. 1991) (holding that a defendant charged with obstructing justice for refusing to testify as a witness may in certain circumstances be entitled to acquittal upon proof that his refusal was based solely upon a realistic and reasonable perception that giving testimony would result in imminent harm to the safety of the witness or members of his family).

118 Singh, supra note 105 , at 1629.

119 United States v. Aguilar, 515 U.S. 593 (1995).

120 Decker, supra note 52, at 54. 
investigation or official proceeding not connected with a pending judicial proceeding.," but a proceeding can be described as pending if an investigation is conducted "as an aid to" or "in furtherance of" the grand jury investigation ${ }^{121}$ While as the subsequent paragraphs highlight, there is considerable debate in the circuits concerning the "pending proceeding” requirement, most scholars agree that there should not be strict adherence to the requirement of a pending proceeding. The Eleventh Circuit explained in United States $v$. Veal, ${ }^{122}$ convictions of obstruction of justice under $\S$ 1503 should not be limited by a jurisdictional basis that strictly requires official proceedings:

[F]ederal jurisdiction under [obstruction of justice statutes is] based on the federal interest of protecting the integrity of potential federal investigations by ensuring that transfers of information to federal law enforcement officers and judges relating to the possible commission of federal offenses be truthful and unimpeded. ${ }^{123}$

An analysis of the federal circuit opinions on the issue of pendency leads one to conclude that there is at least a three-way split in the circuits concerning what gives rise to, ${ }^{124}$ and when is a "pending proceeding" present. The First, Second, Fourth, Ninth, and Tenth Circuits contain decisions where the courts have concluded a pending proceeding is present if there is an investigation related to a sitting grand jury ${ }^{125}$ For instance, in United States $v$. Dwyer, the First Circuit held that defendant who made false statements to FBI agents when a grand jury proceeding was underway and the investigation was in connection to that proceeding, constituted a violation of $\S 1503 .{ }^{126}$ In United States v. Genao, the Second Circuit refused to find a $\S$ 1503 violation because there was no grand jury proceeding at the time the defendant made false statements. ${ }^{127}$ In United States v. Grubb, the Fourth Circuit found false

121 Harrington et al., supra note 51, at 1482 (citing United States v. Aguilar, 515 U.S. 593, 599 (1995) (holding that false statements made to an agent are not sufficient to trigger § 1503 without showing defendant knew his statements would be relayed to a grand jury)); Salazar-Luviano v. Mukasey, 551 F.3d 857, 862 (9th Cir. 2008) (finding that aiding and abetting illegal aliens by helping them escape from custody is not obstruction of justice; "custody" is not a pending judicial proceeding); Macari, 453 F.3d at 936 (holding that investigation by Federal Bureau of Investigation does not constitute a pending proceeding under $\S 1503$ unless it is an extension of a grand jury investigation); United States v. Davis, 183 F.3d 231, 239-40 (3d Cir. 1999) (finding wiretap investigation of defendant is not pending judicial proceeding, and is thus insufficient to invoke § 1503); cf. United States v. Bruno, 383 F.3d 65, 87-88 (2d Cir. 2004) (holding that, to establish conspiracy to commit obstruction of justice, there must be proof that defendants could reasonably foresee the empaneling of a grand jury and that their fraudulent statements would be passed along to the grand jury). But see Torzala v. United States, 545 F.3d 517, 523-24 (7th Cir. 2008) (finding that false statements during an investigation by the FBI, which acts on behalf of the grand jury, is a violation of $\S 1503$ ).

122 United States v. Veal, 153 F.3d 1233, 1250 (11th Cir. 1998).

123 Id.

124 At this juncture, readers should appreciate that in this section the authors have organized and segregated the relevant cases differently than other scholars on the subject. Whereas Harrington and co-authors organized these cases based on general references to a proceeding, the analysis herein is focused on whether in fact a proceeding was in place and ongoing. Thus, it is in this section where legitimate debate will likely continue.

125 Harrington, supra note 51, at 1482.

126 United States v. Dwyer, 238 F. App'x 631, 650 (1st Cir. 2007).

127 United States v. Genao, 343 F.3d 578, 585 (2d Cir. 2003). 
statements to FBI agents in endeavoring to get FBI agents to give false information to grand jury as violative of $\S 1503 .{ }^{128}$ In United States v. Wood, the Tenth Circuit similarly found that where a grand jury was underway, an effort to interfere with said proceeding violates $\S 1503 .{ }^{129}$ In U.S. v. Washington Water Power Co., the Ninth Circuit held "[w]e have previously held that a federal proceeding is "pending" for purposes of $\S 1503$ as soon as a complaint has been filed with a magistrate.”130

Decisions in Third, Sixth, and Seventh Circuits, provide what may be considered a slightly more liberal reading of $\S 1503$, holding that the pending proceeding requirement is met when an investigation is serving as an aid to and arm of a grand jury. In United States v. Monus, the Sixth Circuit held "[o]ur inquiry into whether a grand jury proceeding is pending focuses on 'whether the subpoena is issued in furtherance of an actual grand jury investigation, i.e., to secure a presently contemplated presentation of evidence before the grand jury.", 131 In U.S. v. Davis, the Third Circuit refused to find a pending proceeding where there was a grand jury empaneled, but the government failed to show the grand jury had some relationship to the investigation that was obstructed. ${ }^{132}$

In yet a third line of cases, the Fifth, Second, Seventh, Eighth, Ninth, and Eleventh Circuit Courts of Appeals have decisions within them that have taken a broad view in determining when a proceeding is pending. For instance, in United States $v$. Vesich, the Fifth Circuit found that the pending proceeding requirement was met where defendant did not object to an instruction that "a proceeding was pending" when one was "initiated but not yet settled or decided." 133 Here, the Fifth Circuit appears to have been somewhat lax in terms of what it takes to meet the pending proceeding requirement. The Vesich court specifically stated "we have long held that the issuance of a subpoena is not necessary to trigger application of the obstruction of justice statute.... we too decline to establish a rule "by which some formal act of the grand jury will be required to establish 'pendency." 134 The Vesich court found the determining factor concerning pendency is "whether the subpoena is issued in furtherance of an actual grand jury investigation, i.e., to secure a presently contemplated presentation of evidence before the grand jury." ${ }^{135}$ Similarly, in U.S. v Kumar, the Second Circuit, found "[a]lthough ' $§ 1503$ 's application typically begins after the commencement of formal judicial proceedings,' in this case, [the defendant] concedes that, when he lied, he knew that "formal judicial proceedings" were not only possible or likely, but that the government intended to bring them. Such obstructive behavior during a federal investigation - whether that investigation is conducted by a grand jury, or by a federal agency like the SEC where there is also a "quite strong,

128 United States v. Grubb, 11 F.3d 426, 438 (4th Cir. 1993).

129 United States v. Wood, 6 F.3d 692, 696 (10th Cir. 1993).

130 United States v. Washington Water Power Co., 793 F.2d 1079 (9th Cir. 1998).

131 United States v. Monus, 128 F.3d 376, 389 (6th Cir. 1997) (“Our inquiry into whether a grand jury proceeding is pending focuses on 'whether the subpoena is issued in furtherance of an actual grand jury investigation, i.e., to secure a presently contemplated presentation of evidence before the grand jury."” (quoting United States v. Tackett, 113 F.3d 603, 612 n.6 (6th Cir. 1997))).

132 United States v. Davis, 183 F.3d 231, 239-40 (3d Cir. 1999).

133 United States v. Vesich, 724 F.2d 451, 455 (5th Cir. 1984).

134 Id. at 456.

135 Id. 
perhaps inescapable" inference that the witness's statements "would be presented to [a] grand jury"-is covered by $\S 1503(a) .$. ." 136 Therefore, despite the fairly narrow Second Circuit opinion in Genao, ${ }^{137}$ where the court refused to find pendency because there was no grand jury at the time of the investigation, the same circuit seven years later found a broad reading of $\S 1503$. Thus, the Second Circuit in Kumar, specifically allowed for a finding pendency even in the absence of any proceeding that was underway. In yet another broad reading of pendency, in U.S. v. Marcari, the defendant argued the government failed to establish a pending judicial proceeding because it failed to prove that a grand jury had been empaneled at the time of defendant's alleged act of obstruction of justice. ${ }^{138}$ The Seventh Circuit in Marcari, held a governmental agency investigation can mark the beginning of a judicial proceeding so long as the agency is acting "as an aid to and as an "arm of the grand jury." 139 The court further stated, "in order to establish that an FBI investigation constituted a "judicial proceeding" for purposes of $\S 1503$, the government must establish that the FBI undertook the investigation to supply information to the grand jury on this issue in direct support of a grand jury investigation. ${ }^{140}$ To establish that the FBI was acting as an arm of the grand jury, the government must demonstrate that the FBI agents were "integrally involved" in the grand jury investigation." ${ }^{141}$ Much like the conflict within the Second Circuit, despite the Wash. Power \& Light Co., decision from the Ninth Circuit mentioned above, in United States v. Gonzalez-Mares, the Ninth Circuit found a pending proceeding requirement was met when defendant made false statements to probation officer, even though complaint had not yet been filed and it was immaterial that complaint was filed minutes after interview instead of minutes before. ${ }^{142}$

The Eighth and Eleventh Circuits have taken a broad reading of $\S 1503$ even a step further, and concluded a pending judicial proceeding is not required. ${ }^{143}$ For instance, in United States v. Novak, the Eighth Circuit held "[T]here is nothing on the face of $\S 1503$ requiring a pending proceeding." ${ }^{144}$ The Novak court looked to the history of the obstruction statute and argued the Supreme Court decision in Aguilar, approved the recognition of certain "metes and bounds on the very broad language

136 United States v. Kumar, 617 F.3d 612, 650 n.8 (2d Cir. 2010) (internal citation omitted).

137 Genao, 343 F.3d at 585.

138 United States v. Macari, 453 F.3d 926, 936 (7th Cir. 2006).

139 Id. (quoting United States v. Fassnacht, 332 F.3d 440, 449 (7th Cir. 2003))); see United States v. Monus, 128 F.3d 376, 389 (6th Cir. 1997) ("Our inquiry into whether a grand jury proceeding is pending focuses on 'whether the subpoena is issued in furtherance of an actual grand jury investigation, i.e., to secure a presently contemplated presentation of evidence before the grand jury.”' (quoting United States v. Tackett, 113 F.3d 603, 612 n.6 (6th Cir. 1997))).

140 Id.

141 See Macari, 453 F.3d at 936.

142 United States v. Gonzalez-Mares, 752 F.2d 1485, 1491-92 (9th Cir. 1985).

143 See United States v. Novak, 217 F.3d 566, 572 (8th Cir. 2000) (“[T] 1503 requiring a pending proceeding.”); United States v. Vaghela, 169 F.3d 729, 734 (11th Cir. 1999) (disagreeing with Fifth Circuit and holding that conviction for conspiracy to obstruct justice will not always require pending judicial proceeding to be in existence when defendants formed conspiracy); United States v. Veal, 153 F.3d 1233, 1250 n.24 (11th Cir. 1998) ("In the second and third clauses of § 1503, the federal interest originates from the status of the targeted person, a federal juror, but no judicial proceeding is required.”).

144 United States v. Novak, 217 F.3d 566, 572 (8th Cir. 2000). 
of the catchall provision" and has required some "nexus" between the misconduct and the administration of justice....holding that "uttering false statements to an investigating agent ... who might or might not testify before a grand jury" is insufficient to make out violation of $\S 1503$ 's catch-all provision. ${ }^{145}$ According to the Aguilar Court's "nexus" analysis, "the act must have a relationship in time, causation, or logic with the judicial proceedings." ${ }^{446}$ Similarly, in United States $v$. Vaghela, the Eleventh Circuit, held that conviction for conspiracy to obstruct justice will not require pending judicial proceeding to be in existence when defendants formed conspiracy. ${ }^{147}$ Accordingly, while there may be debate on how to characterize the varying views from the different circuits, the Second, Fifth, Seventh, Eighth, Ninth, and Eleventh Circuits contain opinions from those jurisdictions with liberal interpretations of $\S 1503$ 's pending proceeding requirement.

In the end, it is highly likely that the pending proceeding requirement of $\S 1503$ will be the most debated and potentially litigated issue in a potential Trump impeachment or indictment. While the authority on the matter is filled with differing positions, in the end, a conservative U.S. Supreme Court, if the matter would ever get to the Court, will likely take a plain meaning approach towards $\S 1503$ 's pendency requirement. What is far more likely to occur is that Special Counsel Mueller submits a report to the acting Attorney General Rod Rosenstein or his replacement or superior. If Rosenstein is still in office, he will then forward the report and recommendation to the U.S. House of Representatives for consideration, which may include an impeachment trial. What remains to be seen is whether Robert Mueller's team will conclude that a $\S 1503$ obstruction of Justice charge is warranted. What is far more likely, is that the Special Prosecutor will recommend, or actually pursue charges based on conspiracy to obstruct justice. If the Special Prosecutor concludes the facts warrant such a charge or recommendation, there will be few, if any legal impediments to a conspiracy to obstruct justice charge or recommended charge.

\section{B. Establishing Intent Through the Natural and Probable Consequences Doctrine}

Another required element under $\S 1503$ is the intent requirement. In United States v. Aguilar, the Supreme Court established that for a conviction under $§ 1503$, the acts constituting obstruction must be made with the specific intent to influence judicial or grand jury proceedings. ${ }^{148}$ However, courts have affirmed convictions where specific intent was established through a natural and probable consequences effect:

The government is not required to prove ... that the defendant harbored the specific purpose of obstructing the due administration of justice; all the government has to establish is that the defendant should have reasonably foreseen that the natural and probable consequence of the success of his

145 Id.

146 Id.

147 United States v. Vaghela, 169 F.3d 729, 734 (11th Cir. 1999).

148515 U.S. 593, 599 (1995) (citing United States v. Brown, 688 F.2d 596, 598 (9th Cir. 1982)). 
scheme would achieve precisely that result. ${ }^{149}$

In United States v. Silverman, the Court addressed both the intent and knowledge prerequisites by holding that the natural and probable consequences of paying a lawyer to "fix" a case would be to get favorable sentences, thus interfering with the due administration of justice. ${ }^{150}$ Furthermore, a defendant does not need to know with absolute certainty that his conduct will affect judicial proceedings, nor do his acts need to directly and immediately obstruct justice. ${ }^{151}$ The conduct must only have the "natural and probable effect of interfering with the due administration of justice."152 Therefore, if the act constituting obstruction has some natural and probable "relationship in time, causation, or logic with the judicial proceedings," the defendant intended and knowingly tried to obstruct. ${ }^{153}$

\section{CONSPIRACY TO OBSTRUCT JUSTICE UNDER SECTION 1503}

In what may be most troubling to the Trump team concerning the obstruction of justice statutes is a claim of conspiracy to obstruct justice. Such a claim will likely prove considerably more fruitful to the prosecution in a criminal setting or in an impeachment trial. To sustain a conviction of conspiracy to obstruct justice under $\S$ 1503, the government must establish:

(1) That the defendant:

(a) knowingly entered into an agreement with another,

(b) with knowledge, or at least anticipation, of a pending judicial proceeding, and

(c) with the specific intent to impede that proceeding; and

(2) the commission of at least one overt act in furtherance of the conspiracy. ${ }^{154}$

In addition, the Eleventh Circuit made an important distinction between obstruction of justice and conspiracy to obstruct justice by highlighting the pending proceeding requirement:

In order to sustain a conviction for conspiracy to obstruct justice. . . the government need not always show that a judicial proceeding existed at the time the defendants formed the conspiracy, but must demonstrate that the

149 United States v. Brenson, 104 F3d 1267, 1277 (11th Cir. 1997).

150745 F.2d 1386, 1393 (11th Cir. 1984) (citations omitted) (emphasis added).

151 See United States v. Thomas, 916 F.2d 647, 651 (11th Cir. 1990).

152 Aguilar, 515 U.S. at 599.

153 Id. at 600; see also United States v. Saget, 991 F.2d 702, 713 (11th Cir. 1993) (asking the grand juror to disclose secret information about the grand jury investigation had the natural and probable effect of impeding the due administration of justice); see generally United States v. Neiswender, 590 F.2d 1269, 1274 (4th Cir. 1979) (holding that a defendant who intentionally undertakes an act, the reasonably foreseeable consequence of which is to obstruct justice, violates $\S 1503$ even if his hope is that the judicial process will not be seriously impaired).

154 United States v. Schwarz, 283 F.3d 76, 105-06 (2d Cir. 2002). 
actions the conspirators agreed to take were directly intended to prevent or otherwise obstruct the processes of a specific judicial proceeding in a way that is more than merely "speculative." 155

Although "investigations undertaken with the intention of presenting evidence before a grand jury are sufficient to constitute 'the due administration of justice' under Section 1503," the Seventh Circuit in United States v. Cueto, ${ }^{156}$ held that convictions of conspiracy to obstruct justice must only demonstrate that the conspirators agreed to impede anticipated judicial proceedings. ${ }^{157}$

Thus, when considering a conspiracy to obstruct justice, federal appellate courts from different circuits have made clear that there is no required "pending proceeding" prerequisite under $\S 1503 .{ }^{158}$ As the lead author here wrote over a year ago when the allegations of President Trump's alleged obstruction were first aired:

Federal courts, for instance, have not insisted upon the "pending proceeding" requirement to find the related obstruction violation of conspiracy to obstruct justice. Indeed, several federal courts in more than one federal circuit have recognized, pending proceedings are not required for conspiracies to obstruct justice. ${ }^{159}$

In U.S. v. Vaghela, for instance, the Eleventh Circuit observed that "in order to sustain a conviction for conspiracy to obstruct justice under 18 U.S.C. § 371 and 18 U.S.C. $\S 1503$, the government need not always show that a judicial proceeding existed at the time the defendants formed the conspiracy, but must demonstrate that the actions the conspirators agreed to take were directly intended to prevent or otherwise obstruct the processes of a specific judicial proceeding in a way that is more than merely 'speculative." ${ }^{160}$ Likewise, in U.S. v. Abbell, a federal appellate court stated: "in Vaghela, we said the requirement that defendants' acts have the natural and probable effect of interfering with the due administration of justice is not so narrow as to exclude efforts 'to obstruct specific future judicial proceedings."”161 In Torzala $v$.

155 United States v. Vaghela, 169 F.3d 729, 734 (11th Cir. 1999)); see also United States v. Varela Garcia, 533 F. App’x. 967, 983 (11th Cir. 2013).

156151 F.3d 620, 634 (7th Cir. 1998).

157 United States v. Messerlian, 832 F.2d 778 (3d Cir. 1987) (conspirators who took steps to obstruct a federal proceeding that they anticipated would commence in a future were properly convicted of conspiracy to obstruct justice); see also United States v. Davis, 183 F.3d 231, 243 n.3 (3d Cir. 1999) (“The lack of evidence that a grand jury proceeding was pending is not dispositive on [a count of conspiracy to obstruct justice]" and nexus requirement is satisfied where conspirators "knew of or anticipated a grand jury investigation"); United States v. Perlstein, 126 F.2d 789, 795 (3d Cir. 1942) (holding that overt acts committed two years before a grand jury investigation commenced could not sustain a conviction of obstruction of justice, but defendants could still be charged with conspiracy to obstruct justice in the future, and conspirators who "expect or fear" that federal proceedings will be instituted can be prosecuted for conspiracy to obstruct justice).

158 See e.g., United States v. Vaghela, 169 F.3d 729, 734 (11th Cir. 1999)); see also United States v. Varela Garcia, 533 F. App’x. 967, 983 (11th Cir. 2013).

159 Ediberto Roman, Pundits Misguided on Trump's Alleged Obstruction of Justice Charges, HufFINGTON POST (June 13, 2017,) https://www.huffingtonpost.com/entry/pundits-on-trumps-alleged-obstructionof-justice-charges.

160169 F.3d 729 (11th Cir. 1999).

161271 F.3d 1286 (11th Cir. 2001). 
United States, the Seventh Circuit upheld obstruction of justice charge under § 1503 despite defendant's argument that there was no pending proceeding. The court specifically found that defendant's agreement to the trial court's charge that there was a pending proceeding sufficed to meet $\S 1503$ 's requirements. ${ }^{162}$ Later, in United States v. Kumar, the Second Circuit reiterated the difference between the two offenses by focusing on the conspirator's knowledge and corrupt intent. ${ }^{163}$

Although there is support for a broad reading of $\S 1503$ that includes "investigations undertaken with the intention of presenting evidence before a grand jury are sufficient to constitute 'the due administration of justice' under Section 1503,"'164 the Third Circuit in United States v. Messerlian, made clear that convictions of conspiracy to obstruct justice need only demonstrate that the conspirators agreed to impede anticipated judicial proceedings. ${ }^{165}$ The Messerlian, court found that a violation of the obstruction of justice statutes where conspirators, who took steps to obstruct a federal proceeding that they anticipated would commence in a future, were properly convicted of conspiracy to obstruct justice. ${ }^{166}$ Similarly, in United States v. Davis, the Third Circuit held "[t]he lack of evidence that a grand jury proceeding was pending is not dispositive on [a count of conspiracy to obstruct justice]" and the nexus requirement is satisfied where conspirators "knew of or anticipated a grand jury investigation." And in what may be the most troubling for anyone facing a potential conspiracy to obstruct justice charge, the appellate court in United States v. Perlstein, held that overt acts committed two years before a grand jury investigation commenced could not sustain a conviction of obstruction of justice, but defendants could still be charged with conspiracy to obstruct justice in the future, and conspirators who "expect or fear" that federal proceedings will be instituted can be prosecuted for conspiracy to obstruct justice. ${ }^{167}$

If, in fact, Special Prosecutor Robert Mueller and his team deem the facts in the Trump related investigation to warrant potential allegations of conspiracy to obstruct justice, such a claim will probably not be brought in a courtroom against a sitting president (a matter covered by Section VIII below), but may nevertheless provide the basis for impeachment charges in the House of Representatives. Whereas obstruction of justice claims pursuant to $\S 1503$ may prove to be at the very least the subject of considerable debate, as discussed above concerning the 1503's pending pleading requirement, there is little doubt that if the facts so establish, there is ample legal basis to bring a claim or charge based upon conspiracy to obstruct justice.

In the sections below, other potential legal basis—18 U.S.C. §§ 1510 and $1512-$ for obstruction will be analyzed. This will be followed by a brief overview of purported facts concerning some of the potential claims relating to a potential Trump

162 See Torzala v. United States, 545 F.3d 517 (7th Cir. 2008).

163617 F.3d 612, 621 n. 8 (2d Cir. 2010) ("it is well established that investigations undertaken with the intention of presenting evidence before a grand jury are sufficient to constitute 'the due administration of justice' under section 1503,").

164 United States v. Cueto, 151 F.3d 620, 634 (7th Cir. 1998).

165 United States v. Messerlian, 832 F.2d 778 (3d Cir. 1987).

166 Id.

167126 F.2d 789, 795 (3d Cir. 1942) 
impeachment trial. Finally, the question of whether a sitting president can be prosecuted in a criminal court will be examined briefly.

\section{ObSTRUCTION OF JUSTICE UNDER § 1512: PROTECT WitNesSES, Victims, OR INFORMANTS}

On October 12, 1982, Congress passed Public Law 97-291, referred to as Victim and Witness Protection Act of 1982 ("VWPA"), to provide additional protection and assistance to victims and witnesses in Federal cases. ${ }^{168}$ Section 1512 to Title 18 of the United States Code was originally enacted as part of the Victim and Witness Protection Act of 1982, resulting from Congress's effort to address witness tampering. ${ }^{169}$ In the VWPA, Congress found and declared that under the previous laws, the criminal justice system failed to offer "adequate protection or assistance" when victims and witnesses were threatened or intimidated because of their cooperation with law enforcement agencies. ${ }^{170}$

When Congress passed the Victim and Witness Protection Act of 1982, it explicitly declared that the purposes of the VWPA were: (1) "to enhance and protect the necessary role of crime victims and witnesses in the criminal justice process;” (2) "to ensure that the Federal Government does all that is possible within limits of available resources to assist victims and witnesses of crime without infringing on the constitutional rights of the defendant;" and (3) "to provide a model for legislation for State and local governments." 171 The two former purposes are most relevant to the present discussion. This resulted from Congress's concern with the shortcomings of previously enacted legislation.

Prior to the VWPA, witness protection was limited in scope and inadequate in offering a prosecutor "the appropriate tools to deal specifically with a defendant who influenced or otherwise hindered a witness from providing information to federal law enforcement officers regarding the investigation of a crime.”172 Prior to 1982, § 1503 was the only law available to prosecute obstructive conduct involving witnesses in a federal court proceeding. ${ }^{173}$ In its 1948 version, § 1503 read:

Whoever corruptly, or by threats or force, or by any threatening letter or communication, endeavors to influence, intimidate, or impede any witness, in any court of the United States ... or injures any party or witness in his person or property on account of his attending or having attended such court ... or on account of his testifying or having testified to any matter pending therein, or injures any such grand or petit juror in his person or property on account of any verdict or indictment assented to by him, or on

168 Victim and Witness Protection Act, Pub. L. No. 97-291, 96 Stat 1248 (1982).

169 Id. at Sec. 4.

170 Id. at Sec. 2(a)(1)-(4).

171 Id. at Sec. 2(b).

172 Brian M. Haney, Contrasting the Prosecution of Witness Tampering Under 18 U.S.C. § 1503 and 18 U.S.C. § 1512: Why § 1512 Better Serves the Government at Trial, 9 SufFolK J. TRIAL \& ApP. AdVOC. 57 (2004).

173 Tina M. Riley, Tampering with Witness Tampering: Resolving the Quandary Surrounding 18 U.S.C. S 1503, 1512, 77 WASH. U. L.Q. 249, 253 (1999). 
account of his being or having been such juror, or injures any such officer, commissioner, or other committing magistrate in his person or property on account of the performance of his official duties, or corruptly or by threats or force, or by any threatening letter or communication, influences, obstructs or impedes, or endeavors to influence, obstruct or impede, the due administration of justice, shall be fined not more than $\$ 5,000$ or imprisoned not more than five years, or both. ${ }^{174}$

Under this version of $\S 1503$, the government was required to prove that the actions taken by the defendant were specifically intended to influence a witness. ${ }^{175}$ Furthermore, to prosecute under $\S 1503$, it was required that the judicial proceeding had been initiated. ${ }^{176}$ Lastly, the 1948 version offered limited protection to witnesses, excluding all other persons involved in a judicial proceeding. ${ }^{177}$ More recently, the Eleventh Circuit in United States v. Veal, after examining the legislative history of $\S$ 1512 held " [b]y its wording, § 1512 does not depend on the existence or immanency of a federal case or investigation but rather on the possible existence of a federal crime and a defendant's intention to thwart an inquiry into that crime." 178

The legislative history of $\S 1512$ shows that Congress was quite exhaustive in voicing its concerns with the prior laws. The first concern was "the high threshold of seriousness for the commission of a crime.” 179 For example, $\S 1503$ is limited only to the protection against corruption, threat, and force during a judicial proceeding. Additionally, $\S 1510$ is limited to protection against bribery, misrepresentation, intimidation, force, and threat during a federal investigation. ${ }^{180}$ Neither $\S \S 1503$ nor 1510 protect victims or witnesses against conduct that is "knowingly and maliciously hindering, delaying, preventing or dissuading testimony or reports to law enforcement officers.” ${ }^{181}$ Another concern was that $\S 1503$ failed to extend protection to informants, and $\S 1510$ did not include friends and families of the victim or witness. ${ }^{182}$ Lastly, a concern was that prior to the VWPA, the law did not address verbal harassment as a form of intimidation. ${ }^{183}$ Congress expressed that simple acts such as telephoning a victim, going to their home, or driving by can sometimes be extremely effective in preventing a victim or witness from testifying. ${ }^{184}$

The Victim and Witness Protection Act of 1982 offered an extensive reform to witness tampering. First, the VWPA eliminated all references to witnesses from $\S$ 1503 and added a group of sections under $\S 1512$ to expand the protection afforded

174 Teresa Anne Pesce, Defining Witness Tampering Under 18 U.S.C. Section 1512, 86 ColuM. L. REV. 1417, 1435 (1986) (citing 18 U.S.C. § 1503 (1948) (amended 1982)).

175 Id. at 1419.

176 Id. at 1430 .

177 Haney, supra note 172, at 75.

178 United States v. Veal, 153 F.3d 1233, 1250 n.24 (11th Cir. 1998).

179 S. REP. No. 97-532, 1982 U.S.C.C.A.N. 2515, 2520 (1982).

180 Id.

181 Id.

182 Id.

183 Id. at 2521.

184 Id. 
to victims, witnesses, and potential witnesses. ${ }^{185}$ Additionally, the VWPA did the same with any witness tampering measures in $\S 1505$ regarding federal agencies and legislative proceedings, and in $\S 1510$ regarding federal investigations. ${ }^{186}$ Second, 18 U.S.C. $§ 1512$ "collected the witness-tampering provisions of these three sections (§§ 1503, 1505, and 1510), and broadened their coverage.”187

Under 18 U.S.C. § 1512, Congress "eliminated the burden to prove that a defendant acted with the intent to obstruct justice, by criminalizing tampering of any person, and by eliminating the requirement that a judicial proceeding be pending at the time of the offense." 188 This extended the protection to witnesses of grand jury hearings, official proceedings, and even regulatory and administrative matters. ${ }^{189}$ Furthermore, the use of the term "any person" is construed to include potential witnesses, excused witnesses, grand jury witnesses, and also investigators. ${ }^{190}$ Lastly, § 1512 also included influencing a witness through misleading conduct as a crime. ${ }^{191}$

In 1988, Congress amended $\S 1512$ to include acts that did not involve coercive conduct. ${ }^{192}$ "The amendment changed the language of $\S 1512$ (b) from 'or threatens another person' to 'threatens, or corruptly persuades another person,' thereby making $\S 1512$ (b) applicable to non-coercive forms of witness tampering." 193 A divide exists as to whether the new language in $\S 1512$ was meant to remove witness tampering from the scope of $\S 1503 .{ }^{194}$

In conclusion, Congress enacted 18 U.S.C. § 1512, under the Victim and Witness Protection Act of 1982, as part of a comprehensive effort to correct the shortcomings of the protection offered to witnesses and victims under federal jurisdiction. Section 1512 extended the protection to even potential witness before the commencement of federal judicial proceedings. Furthermore, it broadened the range of conduct considered obstructive to the administration of justice. At this juncture, facts have not been disclosed to conclude any witness tampering has occurred. Whether any witnesses to the Trump-Comey meeting, or witnesses to the Trump Tower meeting were affected is likely a matter being investigated and remains to be seen.

\section{18 U.S.C. $§ 1510$ OBSTRUCTION OF JUSTICE BEFORE THE INITIATION OF JUDICIAL PROCEEDINGS.}

Another potentially relevant obstruction provision in the context of the Trump

185 Haney, supra note 172, at 63. (1984).

186 William Jeffress, Jr., The New Federal Witness Tampering Statute, 22 AM. CRIM. L. ReV. 1, 2

187 Id.

188 Haney, supra note 172, at 64.

189 Singh, supra note 105, at 1627; see also 18 U.S.C. § 1515(a)(1) (2012) (defining "official proceeding” for purposes of $\S \S 1512$ and 1513).

190 Singh, supra note 105, at 1628.

191 Jeffress, supra note 186, at 4.

192 Eric C. Surette, Annotation, Construction and Application of Federal Witness Tampering Statute, 185 A.L.R. Fed. 1, §2(b) (2003).

193 Haney, supra note 172 at 65.

194 Id. at 66; compare Surette, supra note 192 at §2(b), with id. 
investigation is 18 U.S.C. $\S 1510$, which addresses obstruction before the initiation of judicial proceedings. Before the enactment of $\S 1510$ of Chapter 73, Title 18, of the United States Code, it was arguably not a crime to obstruct criminal investigation or inquiry prior the initiation of proceedings within the scope of $\S \S 1503$ or $1505 .^{195}$ To address any loopholes left by previous sections, Congress amended chapter 73, title 18, United States Code to included § 1510 to prohibit the obstruction of criminal investigations of the United States. ${ }^{196}$ "Section 1510 is an extension of $\S \S 1503$ and 1505 and provides potential witnesses and informants with the same protection afforded to actual witnesses, jurors, and others involved in judicial, administrative, or congressional proceedings." 197

On November 3, 1967, Congress passed Public Law 90-123 ${ }^{198}$ to enact $\S 1510$. The Department of Justice had recommend this new section to Tittle 18 because previously it was not a federal crime to harass, intimidate, or assault a potential witness providing information to a federal investigation prior to the commencement of a case. ${ }^{199}$ In its recommendation, the House Committee on the Judiciary noted that $\S \S$ 1503 and 1505 had been construed by the courts as applying only once a proceeding had begun, but not during the criminal investigation. ${ }^{200}$ Furthermore, when addressing the enactment of $\S 1510$, the House Committee expressed the following in the Congressional Record:

Public law 90-123 plugs a loophole in existing law. Previous to its enactment protection against intimidation was, according to court interpretation, available only after a criminal case had reached a court of law. A dangerous inconsistency in the law resulted, for a witness or informant is subject to intimidation, or more violent harassment, at the investigative stage of a case just as surely as he is when and if a case comes to court.

Pretrial intimidation is a favorite tactic of organized crime and provisions of Public law 90-123 are aimed in particular at affording protection to those courageous enough to provide information to Federal agencies on crime syndicate activities. This newly afforded protection should assist the FBI in its efforts to investigate the pernicious activities of organized crime in the United States. ${ }^{201}$

The House Committee had an understandable concern for instances where fear would prevent the initiation of proceedings of the matters under investigation, and thus obstruct justice. ${ }^{202}$ With the previously mentioned concerns, Congress enacted

195 Margaret Shulenberger, Annotation, Construction and Application of 18 U.S.C.A. § 1510 Punishing Obstruction of Criminal Investigations, 18 A.L.R. Fed. 875 (originally published in 1974); see also United States v. Mitchell, 372 F. Supp. 1239, 1250 (S.D.N.Y. 1973)

196 Act of Nov. 3, 1967, Pub.L. No. 90-123, 81 Stat. 362 (1967).

197 Singh, supra note 105, at 1624-25.

198 Act of Nov. 3, 1967, Pub.L. No. 90-123, 81 Stat. 362 (1967).

199 Shulenberger, supra note 195, at §2.

200 Id.

201113 CONG. REC. 37373 (1997).

202 Shulenberger, supra note 195, at §2. 
$\S 1510$ with the purpose of "extending the protection afforded witnesses and jurors in judicial, administrative, and congressional proceedings, to informants and potential witnesses in Federal criminal investigations or inquiries before proceedings have been initiated." 203 Consequently, § 1510 had the purpose of prohibiting the obstruction of a criminal investigation. ${ }^{204}$ Although the House Committee aimed to avoid obstruction of criminal investigations, it explicitly stated that $\S 1510$ could not be used by a Federal investigator to intimidate or harass a potential witness or informant "by reason of his giving false or misleading information about a criminal violation." 205

To establish a prima facie case under $\S 1510$, the government must establish the defendant: (1) willfully endeavored to prevent, by means of bribery, the communication of information relating to the violation of any criminal statute of the United States; ${ }^{206}$ (2) acted to prevent a third person from giving the information to the criminal investigator, and (3) knew that the recipient of the information was a Federal investigator. ${ }^{207}$ Most courts have recognized as an element of the offense the need for the government to prove that at the time the defendant acted, there was a pending federal investigation. ${ }^{208}$ The legislative history of $\S 1510$ highlight the broad range of activities it was intended to address. Indeed, perhaps to highlight its broad sweep, $\S 1510$ 's legislative history indicates that federal protection to witnesses who give information to state officials in violation of federal laws was considered, but deliberately excluded from coverage under $\S 1510 .^{209}$ According to the recommendation of the House Committee, "[i]t should be made clear that under the scope of the act state investigators are not included; only Federal investigators are included." 210

In terms of its limit in the federal context, originally, § 1510(a) would "prohibit willful attempts, by means of bribery, misrepresentation, intimidation, or force or threats of force, to obstruct, delay, or prevent the communication to a Federal criminal investigator of information relating to a violation of a Federal criminal law."211 However, at the present time, $\S 1510$ only punishes endeavors to obstruct justice through bribery due to the addition of $\S 1512$ to Chapter 73, Title 18, of the United States Code in 1982. ${ }^{212}$ Thus, $\S 1510$ extended the scope of protection against obstruction of justice to potential witnesses in federal criminal investigations before a judicial or administrative proceeding is initiated. ${ }^{213}$ Also, $\S 1510$ only applies to

$203 I d$.

204 United States v. Fraley, 538 F.2d 626, 627 (4th Cir. 1976)(citing H.R. REP. No. 90-658 (1967), reprinted in 1967 U.S.C.C.A.N. 1760))

205 H.R. REP. No. 90-658, at 1762 (1967), reprinted in 1967 U.S.C.C.A.N. 1760.

206 Judicial Enforcement, 19 U.S.C §1510(a), (1993).

207 Shulenberger, supra note 195, at §3.

208 Id.; see also United States v. Kozak, 438 F.2d 1062 (3d Cir. 1971); United States v. Carzoli, 447

F.2d 774 (7th Cir. 1971); United States v. Williams, 470 F.2d 1339, 1342 (8th Cir. 1973).

2091967 U.S.C.C.A.N. at 1762.

$210 \mathrm{Id}$.

211 Id. at 1763.

212 Singh, supra note 105, at 1625.

213113 Cong. Rec. 37470 (1967). (House Committee on the Judiciary referring to Public Law 90123: "This law (S. 676) amended Chapter 73, Title 18, United States Code. . . by adding a new section prohibiting the obstruction of Federal criminal investigations before a proceeding has been initiated before a Federal agency, or an inquiry or investigation by the either the Congress or a Congressional committee”). 
federal investigations and to individuals attempting to obstruct justice through bribery.

Federal courts interpreting $\S 1510$ observe that, in terms of the defendant's knowledge, the wrong only requires the "knowing commission of the act of interfering with a federal officer". ${ }^{214}$ In other words, in order to incur criminal liability for interfering with a federal officer, a defendant must entertain merely the criminal intent to do the acts specified in the statute, to forcibly assault, resist, oppose, impede, intimidate or interfere with a federal officer while engaged in, or on account of, the performance of official duties. ${ }^{215}$ Interestingly, the Eleventh Circuit in Davis $v$ Williams, found that words alone may constitute obstruction of justice. ${ }^{216}$ However, the Fifth Circuit in United States v. San Martin, held the use of words, such as making a threat that is no more than a claim of liability for the governmental act is outside the scope of $\S 1510 .{ }^{217}$ The Eleventh Circuit in United States. v. Fields, found that a violation of $\S 1510$ occurs by merely making false statements in anticipation of a judicial proceeding to a government investigator. ${ }^{218}$ Similarly, if words are tantamount to a threat, a court may very well find a violation of the obstruction of justice statutes. ${ }^{219}$ Indeed, even drafting a letter urging a family member not to testify rises to the level of obstructing justice. 220

In the related context of punishment enhancements, the Second Circuit in United States $v$. Sisti, found obstruction of justice where defendant made a phone call to ask a witness whether the witness knew if the defendant committed a wrong. ${ }^{221}$ The Sisti court concluded that the purpose of the phone call was to intimidate the witness despite the fact that there were no words evincing a specific threat. ${ }^{222}$ In a similar context of sentencing enhancements, the Eleventh Circuit found that the use of "code words" could be interpreted to provide the basis for a finding of obstruction of justice. ${ }^{223}$ A federal court in Michigan provided useful guidance concerning the use of words and obstruction of justice, stating " $[t]$ here is no talismanic requirement that a defendant must say, '[d]on't testify' or words tantamount thereto" to have committed obstruction of justice." 224 In perhaps the most aggressive decision on obstruction of justice stems from the Second Circuit decision in United States v. Fasolino, where the court found obstruction where the defendant asked an official acquainted with the judge in question "[c]ould . . . talk to the Judge, take him to lunch?" 25 The defendant in Fasolino then repeated his request in the form of a statement: Appellant then asked

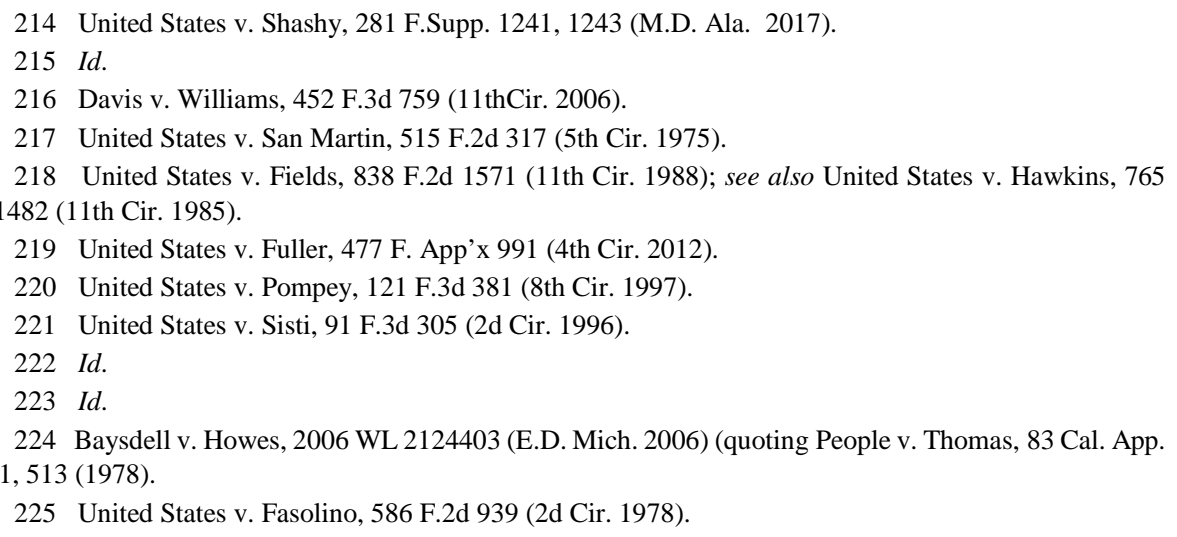


the person that knew the judge to "talk to the Judge and take him out to lunch."226 The Second Circuit did not take kindly to these coy efforts to pressure an official, and made clear, "[t]he crime is one that can be committed merely by words, and words are sometimes misunderstood...but the likelihood of a misunderstanding here was substantially removed by appellant's repetition of the solicitation albeit phrased first as a question and later as a declaration."227

In the context of the Trump investigation, Special Counsel Mueller and his team may very well find that President Trump's effort to persuade FBI Director Comey to halt his investigation of Michael Flynn falls squarely within the purview of $\S 1510$ 's prohibitions. If the facts so establish, and as mentioned above, President Trump denies Comey’s account, § 1510 provides yet another basis for impeachment or federal indictment.

In conclusion, the Act of March 2, 1831, showed the first real effort to combat obstruction of justice in the United States judicial system. The Act distinguished obstruction of justice from contempt and made it into a separate crime. This act survives today through 18 U.S.C. § 1503 which is considered "the wellspring from which most of the obstruction of justice provisions ... arose." 228 Section 1503 is an effective tool to combat obstruction of justice during a federal judicial proceeding. Lastly, Congress enacted and amended $\S 1512$ to correct the shortcomings of the protection offered to witnesses and victims under federal jurisdiction. Finally, Congress enacted $\S 1510$ to extend the scope of protection against obstruction of justice to potential witnesses in federal criminal investigations before a judicial or administrative proceeding is initiated. Section 1510, and $\S 1503$ are likely the provisions most likely to provide the legal basis for any action against President Trump.

\section{IMPEACHMENT AND CRIMINAL Charges AgAinst A SitTing President}

"The President, Vice President and civil officers of the United States shall be removed from Office on Impeachment for, and conviction of, Treason, Bribery, or other high Crimes and Misdemeanors.”

— Article II, section 4, U.S. Constitution.

"Judgment in cases of Impeachment shall not extend further than to removal from Office ... but the party convicted shall nevertheless be liable and subject to Indictment, Trial, Judgment and Punishment, according to law.”

- Article I, section 9, U.S. Constitution.

In terms of the issue of a sitting president being subject to criminal prosecution, most scholars believe that a president can be prosecuted, but there remains considerable debate on the matter. Interestingly, if one is to believe news accounts of conversations between Mueller's team and counsel for President Trump, Mueller and his team have purportedly taken the position that a sitting president cannot face criminal

226 Id.

227 Id.

228 Shtob, supra note 44, at 1435. 
prosecution while in office. ${ }^{229}$ Nevertheless, there is considerable support for the proposition that a president can be prosecuted. Former counsel for Vice President Spiro Agnew, for instance, found "[t]hese passages explain that, despite all the political rhetoric emanating from the White House, the Capitol building and elements of the media, if the House impeached and the Senate convicted Donald Trump, the only result of that Congressional action would be his removal from the Presidency. ${ }^{230}$ According to counsel for the former Vice President, who ultimately resigned his office, "[t]he argument that the President is immune from the criminal laws is just that an argument." 231 Accordingly to Spiro Agnew's counsel, the argument of presidential immunity involves two issues:

First is the question of whether an obstruction of justice charge can be brought in this case. The President's supporters argue that key elements of any such indictment could not support a conviction. If everything the President did was legal, they say, he could not possibly be convicted of a crime. Indeed, the President was legally entitled to ask then-FBI Director James Comey to go easy on former National Security Advisor Flynn, and then fire Comey for that or any other reason-just as he is legally entitled to fire Special Counsel Robert Mueller, Deputy Attorney General Rosenstein or anybody else in the Department of Justice. But the law is clear: an otherwise legal act can be an obstruction of justice if undertaken for corrupt purposes. ${ }^{232}$

In terms of the question of whether a sitting president can be charged and indicted criminally, the former Vice President's counsel goes on to cogently observe:

The second question is not whether, but when. Can the President avoid indictment while in office? But again, there is no language in the Constitution saying he enjoys any such protection. The Department of Justice itself has made this argument before with regards to Article I Officers. I saw it first-hand. During the then-Vice President Spiro Agnew bribery investigation, our legal team argued on behalf of the Vice President that because he was subject to impeachment under Article II, Section 4, he was immune from criminal prosecution unless and until he had been impeached by the House and convicted by the Senate. In effect, we argued that the Vice President had to be impeached and removed from office first-and

229 Robert Costa, et al., Mueller Team Told Trump's Lawyers Special Counsel Cannot Indict a Sitting President, Giuliani says, WASH. POST (May 16, 2018), https://www.washingtonpost.com/politics/muellersteam-told-trumps-lawyers-the-special-counsel-cannot-indict-a-sitting-president/2018/05/16/cf4d5700-596111e8-858f-12becb4d6067_story.html?utm_term=.9a77da09c217; Dana Bash, Giuliani: Mueller's Team Told Trump's Lawyers They Can't Indict a President, CNN (May 17, 2018), https://www.cnn.com/2018/05/16/politics/rudy-giuliani-robert-mueller-indictment/index.html.

230 Martin London, How the President Can Be Prosecuted as a Criminal, Time (Jan. 29, 2018) http://time.com/5123598/president-trump-impeach-criminal-constitution/.

231 Id.

232 Id. 
then criminal charges could proceed. The Department vigorously rejected that claim. They insisted there was nothing in the Constitution that said impeachment was the exclusive remedy for crimes committed by Article I Officers. $^{233}$

More recently, former U.S. Attorney General Eric Holder opined on the immunity issue, and considers presidential immunity from criminal prosecution inconsistent with the U.S. Constitution. Specifically, Holder stated "[a] sitting President can be indicted. [The] Constitution does not anticipate allowing a president who used fraud to obtain the office to remain in power. Executive branch paralysis during the criminal process is not a compelling argument- consider 25th Amendment. A sitting president can be indicted." 234

Federal case law also seems to reject a special immunity for the president. In United States v. Nixon, ${ }^{235}$ the United States Supreme Court heard a related issue: whether a special prosecutor can demand production of certain documents, specifically audio tapes, from the President in connection with an ongoing criminal investigation. ${ }^{236}$ In response, President Nixon's team opposed production, arguing executive privilege. ${ }^{237}$ The Supreme Court concluded "[n]either the doctrine of separation of powers nor the generalized need for confidentiality of high-level communications, without more, can sustain an absolute, unqualified Presidential privilege of immunity from judicial process under all circumstances. ${ }^{238}$ Absent a claim of need to protect military, diplomatic, or sensitive national security secrets, the confidentiality of presidential communications is not significantly diminished by producing material for a criminal trial under the protected conditions of in camera inspection, and any absolute executive privilege under Art. II of the Constitution would plainly conflict with the function of the courts under the Constitution." 239 While the language of the Court's decision is useful, and makes clear that the President of the United States, absent some emergency, is subject to judicial process, the Court's decision in Nixon does not address the broad issue of whether a sitting President can be charged with a crime. A provision of the U.S. Constitution suggests that a president cannot be charged with a crime while in office. By implication, Article I, Section 3 suggests that punishment of the President while he or she is in office cannot go further than removal from office. Specifically, the section states:

Judgment in cases of impeachment shall not extend further than to removal from office, and disqualification to hold and enjoy any office of honor, trust or profit under the United States: but the party convicted shall nevertheless be liable and subject to indictment, trial, judgment and punishment,

233 Id.

234 Eric Holder, (@EricHolder), TwITTER (Feb. 26, 2019, 6:25 PM) https://twitter.com/EricHolder/status/1100582616745549824.

235 United States v. Nixon, 418 U.S. 683 (1974)

236 Id.

237 Id. at 684 .

238 Id.

239 Id. at 685 
according to law. ${ }^{240}$

The above language of the Constitution has not resolved the issue because there remains considerable debate concerning whether a sitting president can be indicted criminally. For instance, Yale Law Professor Akhil Reed Amar has observed " $t$ the framers implicitly immunized a sitting president from ordinary criminal prosecution."241 Eric M. Freedman, a law professor at Hofstra University takes a differing view. In a law review article titled On Protecting Accountability, ${ }^{242}$ Professor Freedman argued that:

[r]eading the Constitution to insulate an incumbent President from criminal liability would not only feed the imperial delusions to which too many high officials in this century have succumbed, but would undermine the fundamental concept of the President as an ordinary citizen temporarily exercising power delegated by We the People. ${ }^{243}$

In terms of the U.S. Department of Justice position on the issue, it is telling that it has previously taken a position on the matter in previous impeachments. During President Nixon's impeachment controversy, attorneys for Department of Justice Office of Special Counsel on February 12, 1974, issued a report sent to the Nixon Special Prosecutor Leon Jaworski, on the issue of the possibility of indicting a sitting president. The report concluded:

This office will soon be called upon by the Watergate Grand Jury for recommendations as to what actions it should take in light of the evidence that has been presented to it. Since this evidence implicates the President in a conspiracy to obstruct justice, the Grand Jury will no doubt be anxious to receive our recommendation, and the reasons therefor, concerning appropriate action with respect to the President. The purpose of this memorandum is to aid the process of decision by focusing attention on two possible courses of action - indictment and presentment - and articulating the reasons for which we believe that one of these courses should be recommended to the Grand Jury. ${ }^{244}$

The facts described to you in a separate memorandum, if proven true constitute clear and compelling prima facie evidence of the President's participation in a conspiracy to obstruct justice. Assuming that the Grand Jury agrees with this assessment, then we are compelled by (1) our mandate to investigate and prosecute allegations involving the President; (2) the Grand Jury's sworn duty to make true presentment of all offenses that come

240 U.S. CONST. art. I, §. 3.

241 Adam Liptak, A Constitutional Puzzle: Can the President Be Indicted? N.Y. TiMEs (May 29, 2017), https://www.nytimes.com/2017/05/29/us/politics/a-constitutional-puzzle-can-the-president-be-indicted.html

242 Eric M. Freedman, On Protecting Accountability, 27 HofsTRA L. ReV. 677 (1999).

243 Id. at 682.

244 Memorandum: Watergate Special Prosecution Force, 27 HofSTRA L. REV. 728, 729 (1999) (Appendix to Freedman, On Protecting Accountability, supra, note 242). 
to its knowledge; and (3) the paramount importance of reaffirming the integrity of the law, to recommend that the Grand Jury express its judgment by the customary method of indictment or (if we conclude indictment is constitutionally barred or is otherwise inappropriate) by a presentment setting out the evidence and the Grand Jury's conclusion of criminal activity. ${ }^{245}$

The February 12, 1974, report found several reasons to support the conclusion that a sitting president could be criminally indicted. Among the primary reasons for the special counsel report's conclusion was "the necessity for vindicating the integrity of the law." 246 The drafters of the report stated that "[n]o principles are more firmly rooted in our traditions, or more at stake in the decision facing this office and the Grand Jury, than that there shall be equal justice for all and that '(n)o man in this country is so high that he is above the law.'”247 The drafters of the 1974 report also specifically rejected the argument that the political process of impeachment is the sole appropriate means to address presidential wrongdoing. The constitutional allocation of these separate functions means that to let "political" considerations of the kind now being debated in Congress intrude upon the decision-making of this office and of the Grand Jury would be to confuse the functions of law enforcement, of impeachment, and the result would be further to undermine public confidence in the integrity of the legal process. ${ }^{248}$

The drafters of the 1974 report ultimately concluded:

Thus, we believe that it would be impermissible for this office to determine its course of action on the basis of a belief that the President should or should not be removed from public office. By the same token, we cannot responsibly leave the question of the President's criminal guilt or innocence to the "political" process and the "political" judgment of impeachment. To do so, we feel, would be an abdication of our duties and those of the Grand Jury, premised only on the view 'that for the most powerful official in the country, the essence of "justice" is limited to the decision of his fitness to govern and to ouster from office if he is found wanting. ${ }^{249}$

The Department of Justice's Office of Special Counsel's addressed the issue a few decades later in the context of President Bill Clinton's impeachment. In a May 13, 1998 letter to Special Counsel Kenneth Starr, Ronald Rotunda, who happens to now be a law professor at Chapman University, addressed the issue. ${ }^{250}$ In the letter,

245 Id.

246 Id. (Appendix p. 4).

247 Id.

248 Id.

249 Id. (Appendix p. 8).

250 Charlie Savage, Newly Discovered Clinton-era Memo Says Presidents Can Be Indicted, N.Y. TIMES (July 22, 2017),https://www.nytimes.com/interactive/2017/07/22/us/document-Savage-NYT-FOIA-Starrmemo-presidential.html (Appendix to the article). 
Professor Rotunda poses the question as follows: "You [Special Counsel Kenneth Starr] have asked my legal opinion as to whether a sitting President is subject to indictment. Does the Constitution immunize a President from being indicted for criminal activities while serving in the office of president?” Rotunda answers the question as follows:

As this opinion letter makes clear, I conclude that, in the circumstances of this case, President Clinton is subject to indictment and criminal prosecution, although it may be the case he could not be imprisoned (assuming that he is convicted and that imprisonment is the appropriate punishment) until after he leaves that office. ${ }^{251}$

In his analysis, Rotunda wrote:

In this country, the U.S. Supreme Court has repeatedly reaffirmed the state that no one is "above the Law." The constitution grants no immunity from the criminal laws...As the judiciary has noted in the past, the President 'does not embody the nation's sovereignty. He is not above the law's commands.... The people do not forfeit through election the right to have the law construed against and applied to every citizen. Nor does the Impeachment Clause imply immunity from routine court process.

Further, there is precedent that elected members of federal office are subject to indictment and conviction. In the case of former Speaker of the House, Jack Maskell, the Congressional Research Office addressed the issue in April 2, 2015, of whether a sitting member of Congress can be convicted criminally and removed from office. ${ }^{252}$ In doing so, it did not question whether a congressional representative could face criminal indictment and conviction. ${ }^{253}$

Taking a different position concerning the President, on September 24, 1973, the Department of Justice Office of Legal Counsel issued a report on the "Amenability of the President, Vice President and other Civil Officers to 'Federal Criminal Prosecution while in Office."”254 The report held that:

[A]s a general proposition the Constitution does not require ---that an officer of the United States be impeached before criminal proceedings may be instituted against him. In the second part we concluded that by virtue of his unique position under the Constitution the President cannot be the object of criminal proceedings while he is in office. ${ }^{255}$

$251 I d$.

252 Jack Maskell, Cong. Research Serv., RL34716, Status of a Senator Who Has Been INDICTED FOR OR CONVICTED OF A FELONY (2015), available at https://fas.org/sgp/crs/misc/RL34716.pdf. 253 Id.

254 Memorandum from Robert G. Dixon Jr., U.S. Assistant Att'y Gen., on the Amenability of the President, Vice President and Other Civil Officers to Federal Criminal Prosecution While in Office, to Elliot Richardson, U.S. Att’y Gen. (Sept. 24, 1973), available at https:/fas.org/irp/agency/doj/olc/092473.pdf. . 255 Id. at 33. 
The 1973 DOJ report further held:

Thus it appears that under our constitutional plan it cannot be said either: the courts have the jurisdiction over the President as if he were an ordinary citizen or that the President is absolutely immune from the jurisdiction of the courts in regard to any kind of claim. The proper approach is to find the proper balance between the normal functions of the Presidency. ${ }^{256}$

The report further reasoned, "in view of the unique aspects of the Office of the President, criminal proceedings against a President in office should not go beyond a point where they could result in so serious interference with the President's performance of his official duties that it would amount to an incapacitation." 257 Finally, the report observes, "the President is the symbolic head of the Nation. To wound him by a criminal proceeding is to hamstring the operation of the whole governmental apparatus, both in foreign and domestic affairs."258

An October 16, 2000 report by the Department of Justice reached a similar conclusion. ${ }^{259}$ The memorandum from the Office of Legal Counsel stated:

In 1973, the Department concluded that the indictment or criminal prosecution of a sitting President would impermissibly undermine the capacity of the executive branch to perform its constitutionally assigned functions. We have been asked to summarize and review the analysis provided in support of that conclusion, and to consider whether any subsequent developments in the law lead us today to reconsider and modify or disavow that determination. We believe that the conclusion reached by the Department in 1973 still represents the best interpretation of the Constitution. ${ }^{260}$

In the conclusion of the 2000 Report, the Office of Legal Counsel provided:

In 1973, the Department of Justice concluded that the indictment and criminal prosecution of a sitting President would unduly interfere with the ability of the executive branch to perform its constitutionally assigned duties, and would thus violate the constitutional separation of powers. No court has addressed this question directly, but the judicial precedents that bear on the continuing validity of our constitutional analysis are consistent with both the analytic approach taken and the conclusions reached. Our view remains that a sitting President is constitutionally immune from indictment

256 Id. at 24.

257 Id. at 29.

258 Id. at 30.

259 Memorandum from Randolph D. Moss, U.S. Assistant Att’y Gen., on a Sitting President’s Amenability to Indictment and Criminal Prosecution, to Janet Reno, U.S. Att'y Gen. (Oct. 16, 2000), available at https://www.justice.gov/olc/opinion/sitting-president\%E2\%80\%99s-amenability-indictment-and-criminalprosecution.

260 Id. at 222. 
and criminal prosecution. ${ }^{261}$

The opinions of the Special Counsel's office in both the Nixon and Clinton impeachment investigations as well as the arguments set forth by the Professor Freedman are thoughtful, and are far more persuasive than those that believe in an absolute form of presidential immunity. ${ }^{262}$ The defenders of presidential immunity focus on the importance of the office of the presidency and the need to not have the president encumbered by the threat of criminal prosecution. However, this argument in favor of immunity fails in one significant and consequential regard: it effectively presupposes a sitting president cannot also be a criminal. What if, as is believed by many, largely based on news reports at this point, President Trump in fact elevated to the highest office in this land by virtue of breaking the law. If so, should he not only avoid prosecution, but also remain in an office he illegitimately acquired? In other words, should presidential immunity allow for a criminal in the White House? Indeed, one of the President' most recent and troubling allegations comes from his former counsel. And though the facts at the time of this publication of this Article are still being developed, evidently the President's long-time attorney, Michael Cohen, recently testified before a House of Representative Oversight Committee on, among other things, President Trump's alleged violations of federal law. ${ }^{263}$ Cohen testified President Trump, in violation of federal campaign finance laws, signed checks paying-off a former adult film star, Stormy Daniels, in order to obtain her silence concerning her affair with Donald Trump. ${ }^{264}$ If the copy of a check signed by President Trump, provided by Mr. Cohen during his congressional testimony, and made to Cohen is proven to be issued for the purpose of paying off Ms. Daniels in order to avoid public scrutiny and assist then candidate Trump in his election efforts, ${ }^{265}$ such evidence may indeed be persuasive evidence of criminal conduct. This check may be the latest piece of evidence, and but one of many allegations in this matter that if proven true, establish the President has engaged in criminal activities. Thus, if in fact President Trump, in addition to the many other potential claims against him, by virtue of his efforts at silencing a news story concerning his infidelity in order to ensure he would win the presidency, he would have violated federal law, and the country may in fact have a criminal in the White House. Such a possibility, if true, obviously leads to horrific and utterly untenable results, and no theoretical argument of immunity due to how important the office of the presidency is should allow for anyone to obtain the office of the presidency through criminal acts.

The more appropriate approach to the immunity issue is one which does not provide for a form of imperial immunity that would in effect sanction criminal conduct. Indeed, the law should emphasize democratic principles that all citizens are (1) equal;

261 Id. at 260.

262 Freedman, supra note 242; see also Eric M. Freedman, The Law as King and The King as Law: Is a President Immune From Criminal Prosecution Before Impeachment?, 20 HASTINGS ConsT. L.Q. 7 (1992).

263 Betsy Woodruff, Cohen Is Prepared to Say Who Signed His Stormy Daniels “Cover-up Checks”, THE DAILY BEAST (Feb. 26, 2019), https://www.thedailybeast.com/michael-cohen-is-prepared-to-say-whosigned-his-stormy-daniels-cover-up-checks

264 Id.

265 Michael Cohen Congress Testimony: Trump's Former Lawyer Reveals All - FULL STREAM, YouTuBE (Feb. 27, 2019), https://www.youtube.com/watch?v=s0QvW0zO2f0 
(2) owe the very same duties to follow the law; and (3) no citizen is above the law. It is simply indefensible to give a president a blanket protection from the law if in fact the president obtained the very status by breaking the law. Absent an existing national security reason, such as an ongoing unprovoked war, no President should have complete criminal immunity, especially if he or she committed crimes to obtain the office of the presidency. ${ }^{266}$ A president, as Professor Freedman has argued, should be treated as a citizen that happens to hold an office for a period of time, and therefore should be subject to our criminal law, thereby making the President subject to criminal indictment if the facts warrant it. Further, the very office of the presidency and the power it yields should give all pause to ensure the office cannot be used to engage in a potential variety of wrongs.

Notwithstanding two differing views from the Office of Legal Counsel, the 1973 and 2000 opinions of the Office of Special Counsel mirror many of the arguments of Professor Freedman, arguably the country's leading scholar on the matter. The opposing view against indicting a sitting president for the most part focuses on the argument that to allow indictment will simply do too much harm to the country if in fact it becomes the basis to allow a wrongdoer to keep an office obtain through criminal conduct. Such a stance not only invites avoidance of the law by our country's highest official, it effectively puts that official above the law. Such a position falls under its own weight: if a president cannot be subject to our criminal laws because the duties of the president are just too important, doesn't that same argument apply to thwart any efforts at removing a sitting president, by impeachment or otherwise? Under this tortured logic, the office of the presidency is just too important to have a president impeached. Obviously, Article II's Impeachment Clause rejects such an absurd defense of the office and its duties. Therefore, the positions supporting indictment appropriately focus on fundamental values of equality, transparency, and accountability. These values ultimately lead the authors here to the inevitable position that a president should be subject to criminal indictment if the facts warrant it.

\section{Various Factual Allegations that May Give Rise to Obstruction CHARGES}

The focus of the next section is to briefly provide an overview of the facts behind the two leading factual allegations associated with a potential Trump obstruction of justice charge. The first pertains to the Michael Flynn investigation, and related facts including the now-infamous Trump-Comey meeting, and ultimate Comey firing. The second pertains to the Trump Tower meeting, and the alleged involvement before and after the meeting by President Trump.

\section{A. The Michael Flynn Investigation, the Comey-Trump Meeting, and Ultimate Comey Firing}

In order to put a factual basis related to the legal analysis addressed earlier, an overview of the factual accounts relating to various acts President Donald Trump is

266 See Freedman, supra, note 242, at 726. 
accused of undertaking will be set forth. After each factual recitation, a brief legal analysis will be undertaken pursuant to the obstruction of justice statutes discussed above. The first of many factual allegations relating to the Trump administration seem to be concerning former National Security Advisor Michael Flynn. Early on in the Trump administration, Flynn became the center of scandal when according to Vice President Pence and others, Flynn was caught lying to Pence about the details of a phone call Flynn made to Russian Ambassador Sergey Kislyak. ${ }^{267}$ It was reported that Flynn discussed sanctions against Russia with Kislyak, and then lied to federal investigators about the contents of the call. ${ }^{268}$

A month before President Trump took office, his national security adviser, Michael Flynn, held a private conversation with the Russian Ambassador to the United States, Sergey Kislyak. ${ }^{269}$ At first, transition officials stated that the purpose of the call had been to discuss a Trump-Putin telephone call after the inauguration and for Kislyak to extend an invitation to Trump administration to visit Kazakhstan. ${ }^{270}$ The call prompted speculations of whether the topic of sanction on Russia was also discussed in the conversation. ${ }^{271}$ The timing of the call coincided with the Obama administration's announcement that new sanctions would be imposed in response to Russian interference in the 2016 Presidential election. ${ }^{272}$ Furthermore, it was reported on December 30, 2016, that President Vladimir Putin had announced that he would not retaliate against President Obama's decision to impose new sanctions and expel Russian diplomats. ${ }^{273}$ In addition, Putin issued a statement that read:

While we reserve the right to take reciprocal measures, we're not going to downgrade ourselves to the level of irresponsible 'kitchen' diplomacy. . . . In our future steps on the way toward the restoration of Russia-United States relations, we will proceed from the policy pursued by the administration” of Donald J. Trump. ${ }^{274}$

This announcement came as a surprise since the United States and Russia have a long history of "reciprocal explosions," and Russian officials had been threatening to retaliate against the Obama imposed sanctions. ${ }^{275}$ Even the Russian foreign minister,

267 Zachary Fryer-Biggs, Comey Interview: There's “Evidence” Trump Obstructed Justice, Vox, (Apr. 16, 2018), https://www.vox.com/2018/4/16/17241750/comey-trump-obstructed-justice-abc-interview.

268 Id.

269 Karen DeYoung, \& Greg Miller, First Sign of Enhanced U.S.-Russia Relations Under Trump: An Invite to Syria Talks, WASH. POST (Jan. 13, 2017), https://www.washingtonpost.com/world/national-security/first-sign-of-enhanced-us-russia-relations-under-trump-an-invite-to-syria-talks/2017/01/13/81d443d6d9b9-11e6-9f9f-5cdb4b7f8dd7_story.html?utm_term=.632e4d65e333.

270 Id.

271 Id.

272 Id.; see also Glenn Kessler, Michael Flynn’s Guilty Plea: A Comprehensive Timeline, WASH. POST (Dec. 1, 2017), https://www.washingtonpost.com/news/fact-checker/wp/2017/12/01/michael-flynns-guiltyplea-a-comprehensive-timeline/?utm_term=.fc25fced9c35.

273 Neil MacFarquhar, Vladimir Putin Won't Expel U.S. Diplomats as Russian Foreign Minister Urged, N.Y. TimES (Dec. 30, 2016), https://www.nytimes.com/2016/12/30/world/europe/russia-diplomats-ushacking.html?_r=0.

274 Id.

275 Id. 
Sergey V. Lavrov, had recommended measures to retaliate on national television. ${ }^{276}$

As Inauguration Day approached, the Obama admiration grew more suspicious of possible interaction between the Trump associates and Russian officials. ${ }^{277}$ On January 2, 2017, Obama administration officials found out about the telephone conversation between Flynn and Kislyak on December 29, the same day the new Russian sanctions were announced. ${ }^{278}$ On January 12, 2017, the news of the telephone conversation publically broke and a Trump official confirmed them. ${ }^{279}$ The following day, then-White House Press Secretary, Sean Spicer, denied that Flynn discussed sanctions with Kislyak. ${ }^{280}$ On January 14, 2016, Michael Flynn informed Vice President Mike Pence that he had not discussed Russian sanction in his conversation. ${ }^{281}$ In turn, the Vice President went on to defend Flynn on a series of televised shows the following day. ${ }^{282}$

On January 22, 2017, after being sworn in as President Trump's National Security Advisor, it was reported that Michael Flynn was under counterintelligence investigation for communications with Russian officials. ${ }^{283}$ This officially made Flynn the first person under the Trump White House to come under scrutiny due to contact with the Russian government. ${ }^{284}$ The next day, during the administration's very first White House briefing, Sean Spicer stated that during Flynn and the Russian Ambassador's conversation four subjects were discussed. ${ }^{285}$

One was the loss of life that occurred in the plane crash that took their military choir, two was Christmas and holiday greetings, three was to - to talk about a conference in Syria on ISIS and four was to set up a - to talk about after the inauguration setting up a call between President Putin and President Trump. In the past Michael Flynn had an amicable relation. ${ }^{286}$

When further questioned, Sean Spicer stated that the conversation had been limited to those topics and that General Flynn had said so himself. ${ }^{287}$ On this same note,

$276 I d$.

277 Matthew Rosenberg, Adam Goldman, \& Michael S. Schmidt, Obama Administration Rushed to Preserve Intelligence of Russian Election Hacking, N.Y. TIMES (Mar. 1, 2017), https://www.nytimes.com/2017/03/01/us/politics/obama-trump-russia-election-hacking.html?_r=0.

278 Id.

279 David Ignatius, Why did Obama Dawdle on Russia's Hacking?, WASH. Post (Jan. 12, 2017), https://www.washingtonpost.com/opinions/why-did-obama-dawdle-on-russias-hacking/2017/01/12/75f878a0d90c-11e6-9a36-1d296534b31e_story.html?utm_term=.cf73f67181c4.

280 Id.

281 Gregor Aisch, K.K. Rebecca Lai, \& Karen Yourish, Timeline: What We Now Know About Flynn's Phone Calls With Russia, N.Y. TiMES (updated Mar. 1, 2017), https://www.nytimes.com/interactive/2017/02/14/us/politics/flynn-call-russia-timeline.html?mtrref=www.politifact.com. 282 Id.

283 Carol E. Lee, Devlin Barrett, \& Shane Harris, U.S. Eyes Michael Flynn's Links to Russia, WALL STREET J. (Jan. 22, 2017), https://www.wsj.com/articles/u-s-eyes-michael-flynns-links-to-russia-1485134942. 284 Id.

285 C.Q., White House Briefing by Sean Spicer - Full Transcript, CBS NeWs (Jan. 23, 2017), https://www.cbsnews.com/news/sean-spicer-press-conference-transcript-jan-23-2017/.

286 Id.

287 Id. 
the Federal Bureau of Investigations (FBI) asked Michael Flynn about his conversation with Sergey Kislyak and whether he had discussed the new Russian sanctions. ${ }^{288}$ In response, Flynn denied discussing U.S. sanctions against Russia with the ambassador Sergey Kislyak. ${ }^{289}$

On January 26, 2017, the Justice Department informed the Trump administration that its National Security Advisor had not been truthful about his interaction with the Russian ambassador, and that "he could be at risk for being for being blackmailed by Russian intelligence.” 290 Consequently, the FBI interview put Flynn in legal jeopardy as lying to the FBI is a felony. ${ }^{291}$ In February, Flynn contradicted his previous statements when he changed his story to say that "while he had no recollection of discussing sanctions, he couldn't be certain that the topic never came up." 292 Shortly after, the White House announced that President Trump was evaluating the controversy surrounding Michael Flynn and discussing with Vice President Pence about the disputed telephone conversation. ${ }^{293}$ Later in a televised interview on February 13, Kelly Ann Conway, a White House Counselor, said that Michael Flynn still had the "full confidence" of President Trump. ${ }^{294}$ Later, on that same day, Michael Flynn resigned as National Security Advisor to the Trump administration. ${ }^{295}$ As part of his resignation letter, Flynn said that during the course of his duties he had "inadvertently briefed the Vice President-Elect and others with incomplete information regarding [his] phone calls with the Russian Ambassador.”296 Flynn's sudden exist marked the shortest tenure for a National Security Advisor in the history of the position. ${ }^{297}$

On March $30^{\text {th }}$, Flynn offered to testify in front of the House and Senate Intelligence Committees that were conducting investigations into the Trump-Russia ties in exchange for immunity. ${ }^{298}$ Furthermore, Flynn's attorney, Robert Kelner, stated that "General Flynn certainly has a story to tell, and he very much wants to tell it, should circumstances permit." ${ }^{299}$ However, a congressional official stated that investigators

288 Sari Hoewitz \& Adam Entous, Flynn in FBI Interview Denied Discussing Sanctions with Russian Ambassador, DENVER POST (Feb. 16, 2017), https://www.denverpost.com/2017/02/16/flynn-denies-discussingsanctions-with-russia-to-fbi/.

289 Id.

290 Aisch et al., supra note 281.

291 Sari Hoewitz et al., supra note 288.

292 Aisch et al., supra note 281.

293 David Jackson \& Gregory Korte, Trump is 'Evaluating Situation’ About Flynn, Spokesman Says, USA TODAY (Feb. 13, 2017), https://www.usatoday.com/story/news/politics/2017/02/13/flynn-apologizes-after-admitting-he-may-have-discussed-sanctions-russia/97852248/.

294 Jonathan Easley, Conway: Trump Has 'Full Confidence' in Flynn, THE HILL (Feb. 13, 2017), http://thehill.com/homenews/administration/kellyanne-conway-michael-flynn-president-trump-full-confidence.

295 Sara Murray, Gloria Borger, \& Jeremy Diamond, Flynn Resigns Amid Controversy Over Russia Contacts, CNN (Feb. 14, 2017), https://www.cnn.com/2017/02/13/politics/michael-flynn-white-house-national-security-adviser/index.html.

296 Id.

297 Id.

298 Mark Mazzetti \& Matthew Rosenberg, Michael Flynn Offers to Testify Before Congress in Exchange for Immunity, N.Y. TiMEs (Mar. 30, 2017), https://www.nytimes.com/2017/03/30/us/politics/michaelflynn-congress-immunity-russia.html.

299 Id. 
were unwilling to make a deal until they were further along in their investigation. ${ }^{300}$ Later in the year, Flynn was formally charged with making a false statement to the FBI about his communications with the Russian Ambassador. ${ }^{301}$ As it turns out, there was evidence that Flynn had urged Sergey Kislyak "to refrain from escalating the situation in response to sanctions that the U.S. had imposed against Russia." $302 \mathrm{Mi}$ chael Flynn pleaded guilty. ${ }^{303}$ The following day, Trump tweeted that he "had to fire” Flynn because he'd lied to the FBI, seemingly confirming that he knew Flynn had committed a crime when he got rid of him. ${ }^{304}$ Trump's lawyer, John Dowd, who recently left the President's legal team, later claimed he had written the tweet, and that it was incorrect. ${ }^{305}$

After Flynn resigned, FBI Director James Comey took into his own hands the responsibility of finding out what occurred with those phone call conversations. ${ }^{306}$ It was then reported by the New York Times in May 2017, that a conversation between Trump and Comey took place in the Oval Office that is said to be the center of Mueller's obstruction of justice investigation. ${ }^{307}$ During the meeting, Trump purportedly told Comey to "let this go," meaning Trump was asking the FBI to stop investigating Flynn. ${ }^{308}$ Comey then discussed the meeting in an interview with ABC News. Comey stated that Trump's comment was more of a "direction" rather than a suggestion. ${ }^{309}$ At first, Trump denied telling Comey to back off the investigation, but his son went on television to claim that his father's words were not meant as an order, but as a "hey, hope this happens" suggestion. ${ }^{310}$ Obviously, these two accounts by members of the Trump family contradict each other. How can President Trump's son, Donald Trump Jr., argue that his father's words were not meant to be taken literally when Trump denied even saying those words at all?

With respect to related facts, President Trump eventually fired Comey on May 9, 2017, and according to Comey, the firing was due to Comey's failure to swear loyalty, the fact that Comey continued the investigation, and because Comey refused to state publicly that the President was not under investigation. ${ }^{311}$ The official White House statement on May $9^{\text {th }}$ concerning the firing was that the President “acted based

300 Id.

301 Tom Winter \& Andrea Mitchell, Michael Flynn Pleads Guilty to Lying to FBI in Mueller Probe, NBC NEWS (Dec. 1, 2017), https:/www.nbcnews.com/politics/politics-news/michael-flynn-former-nationalsecurity-adviser-plead-guilty-mueller-probe-n825551.

302 Id.

303 Id.

304 Fryer-Biggs, supra note 267.

305 Id.

306 Id.

307 Michael S. Schmidt, Comey Memo Says Trump Asked Him to End Flynn Investigation, N.Y. TIMES (May 16, 2017), https://www.nytimes.com/2017/05/16/us/politics/james-comey-trump-flynn-russia-investigation.html.

308 Id.

309 Fryer-Biggs, supra note 267.

310 Id.

311 Clark Mindock, Trump Fired Comey Because He Refused to Assure the President FBI's Russia Probe Was Not Targeting Him, says Rudy Guiliani, InDEPENDENT (May 3, 2018), https://www.independent.co.uk/news/world/americas/us-politics/giuliani-trump-russia-probe-comey-latest-robert-mueller-targeta8333826.html. 
on the clear recommendations” of the Attorney General and Deputy Attorney General. ${ }^{312}$ President Trump, in an interview two days later, said he was going to fire Comey "regardless of recommendation." 313 Then, somewhat shockingly, in a May $11^{\text {th }}$ television interview with Lester Holt, President Trump admitted that:

[Rosenstein] made a recommendation, but regardless of recommendation "I was going to fire Comey, knowing there was no good time to do it," Trump said. "And, in fact, when I decided to just do it, I said to myself, I said, you know, this Russia thing with Trump and Russia is a made-up story. It's an excuse by the Democrats for having lost an election that they should have won. ${ }^{314}$

Thus, according to the President's television admission, the Comey firing and the reason for it, appears to be directly connected to Comey investigation of Michael Flynn and Flynn's connection to Russia. Accordingly, President Trump's firing of FBI Director Comey may be deemed related to any potential obstruction charge concerning Flynn, or may provide an independent basis for an obstruction charge, particularly under $\S 1510$, which addresses obstruction before the initiation of judicial proceedings. If, in fact, President Trump attempted to thwart an ongoing investigation, and ultimately fired the FBI Director conducting that investigation such actions may very well fall under both 18 U.S.C. § 1503, and 18 U.S.C. § 1510.

An interesting recent approach Mueller is taking to get more evidence against Trump is by scrutinizing Trump's tweets. The famous forum of Twitter has been used by the President as a communication platform for mounting attacks on celebrities and political rivals. Although Trump has been legally advised to avoid social media platforms to announce his "next moves," he seems to enjoy the attention it brings. The attention Trump once loved can now turn dirty as Mueller is reviewing every single tweet to find any kind of piece of evidence on a potential obstruction of justice case. ${ }^{315}$ As of today, Mueller and his team are focusing on four findings on his case of obstruction of justice against the President. First, Trump's intent to fire former FBI Director James Comey. Second, his role in the crafting of a misleading public statement on the nature of a June 2016 Trump Tower meeting between his son and Russians. Third, Trump's dangling of pardons before grand jury witnesses who might testify against him. ${ }^{316}$ Fourth, ${ }^{317}$ pressuring Attorney General Jeff Sessions

312 Eugene Kiely, Why Trump Fired Comey, FACTCHECK.org (May 11, 2017), https://www.factcheck.org/2017/05/trump-fire-comey/.

313 Id.

314 Id.

315 Id.

316 Without more facts that neither the media or lead attorney here has unearthed, it appears a claim of so-called "dangling of pardons" without more, may be extremely difficult to prove was done for an improper purpose. Obviously, as President, Trump has the power and ability to pardon those convicted of crimes. While it is certainly unseemly, and perhaps even embarrassing to think a president would use that power in a corrupt fashion, we have seen many odd occurrences in recent times. Proving obstruction, however, in such circumstances, even if pardons arise, will be extremely difficult, if not impossible to establish. There may, however, be facts only Special Prosecutor Mueller and his team possess on the matter.

317 For many of the same reasons stated in the previous footnote, without more facts that are currently unavailable and which the Special Prosecutor and his team may possess, it seems to be a fruitless task at this 
not to recuse himself from the Russia investigation. ${ }^{318}$ According to Lisa Kern Griffin, a criminal law expert at Duke University, "if Trump exercises his power-even his lawful power- with a corrupt motive of interfering with an investigation, that's obstruction." 319 Given the back-and-forth defenses by Trump, his son, and the Trump defense team, it seems like Mueller's case may very well be stronger than what was first thought.

In terms of the potentially applicable obstruction of justice laws, if in fact former FBI Director James Comey's account of the Trump meeting is deemed accurate, President Trump may very well have violated several federal obstruction of justice laws. Each of these violations may not only give rise to impeachment as a high crime and misdemeanor, it may subject President Trump to indictment. First, if Trump's "requests" that FBI Comey end his investigation of Michael Flynn are deemed enough to satisfy an effort to threaten or otherwise intimidate Comey to halt the investigation, President Trump may be found to have obstructed justice under 18 U.S.C $§ 1503$. Section 1503's requirement of a pending proceeding under a classic obstruction charge will invariably be the subject of debate. Given time constraints and the nature of political maneuvering, resolution of a claim brought under a traditional obstruction charge will likely occur in a courtroom setting with an indictment, if one is ever brought, instead of the political process, that is, impeachment. There is nevertheless at least a colorable basis to make the legal argument for an obstruction of justice charge under $\S 1503$.

If President Trump "requested” Director Comey to end the Flynn investigation, but in reality the so-called request was nothing more than the most powerful person in the world telling a subordinate what that subordinate should do, then President Trump may have obstructed justice. Notwithstanding the pendency argument, Trump apparently sought to obtain something otherwise forbidden by law-the termination of an FBI investigation against his ally-Michael Flynn. There is evidence suggesting that Trump discussed (or communicated his plan to discuss) the Flynn issue with Comey. It is undisputed that Attorney General Jeff Sessions and Trump's then-Chief of Staff, Reince Priebus, left Comey alone with Trump to allow them to discuss the Flynn investigation. ${ }^{320}$ If so, then these two cabinet members may have unwittingly been part of an otherwise unlawful conspiratorial undertaking under $\S 1503$. The facts concerning this matter will turn on a question of credibility. There is little doubt what Trump thinks of Comey, as evidenced by his tweets: "James Comey is a proven LEAKER \& LIAR. Virtually everyone in Washington thought he should be fired for the terrible job he did-until he was, in fact, fired. He leaked CLASSIFIED information, for which he should be prosecuted. He lied to Congress under OATH. He is a weak and...” ${ }^{321}$ In yet another poignant presidential assessment, President Trump wrote: “...untruthful slime ball who was, as time has proven, a terrible Director of the

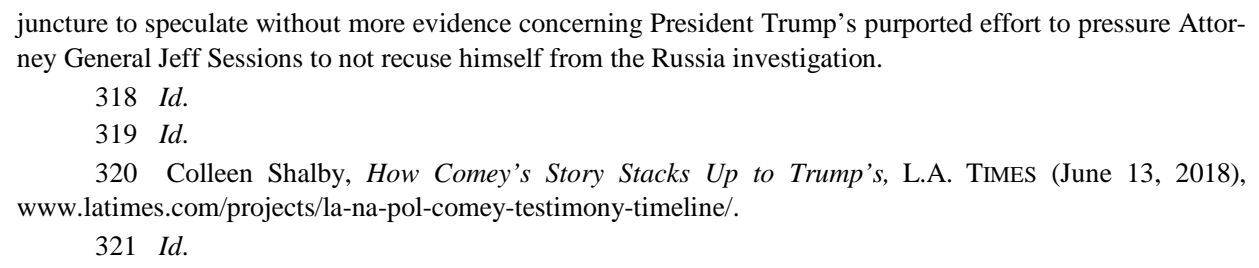


FBI. His handling of the Crooked Hillary Clinton case, and the events surrounding it, will go down as one of the worst "botch jobs" of history. It was my great honor to fire James Comey!”322 Director Comey, for his part, is far from being able to pick up the biblical stone as he recently wrote a book addressing the meeting, among other things, obviously profiting from his experience in the midst of a historic investigation-from a principled perspective, poor timing at the very least. In the end, the question will turn on these and perhaps additional facts Special Prosecutor Mueller has concerning the meeting. If they support Comey's account, a conspiracy to obstruct justice recommendation or charge is likely, and an obstruction of justice charge or recommendation may also be brought. In addition, if there are any facts where potential witnesses or other officials, including Reince Priebus, Jeff Sessions, James Comey, or any other person aware of the details of the Trump-Comey meeting were threatened or intimidated by anyone in the administration, there is the additional possibility of claims being brought pursuant to 18 U.S.C. $\S \S 1510$ and 1512 . Obviously, there would have to be facts supporting such intimidation efforts, a matter, if at all present, at this juncture is exclusively within knowledge of the Special Prosecutor and his team.

\section{B. Trump Tower Meeting and Subsequent Explanation}

On June 3, 2016, Rob Goldstone, a music publicist who had helped the Trump organization bring the 2013 Miss Universe Pageant to Russia sent an email to Donald Trump Jr. ${ }^{323}$ On June 9, 2016, the Trump Tower gathering took place. ${ }^{324}$ Despite initial untruths from the Trump camp, the purpose of the meeting was to exchange information and official documents that would incriminate Hillary Clinton, and her dealings with Russia. ${ }^{325}$ Trump Jr., Goldstone, Jared Kushner, and Paul Manafort attended the meeting, ${ }^{326}$ and testified that Clinton was only briefly discussed, and no documents were exchanged. ${ }^{327}$ The following eight people evidently were present in the Trump Tower meeting: Donald Trump Jr., Jared Kushner, Paul Manafort, Rob Goldstone, Natalia Veselnitskaya, Rinat Akhmetshin, Anatoli Samochornov, and Irakly Kaveladze. ${ }^{328}$ The Russian participants were: Natalia Veselnitskaya, a prominent Russian Lawyer who, in 2018, evidently said she was an "informant of the Kremlin, and that's she's been actively communicating with the office of the Russian prosecutor general since 2013;” ${ }^{329}$ Rinat Akhmetshin, a Russian Lobbyist against the

322 Id.

323 Id.

324 Id.

325 Abigail Simon, What We Know About the Controversial 2016 Trump Tower Meeting With Russian Officials, TiME (July 27, 2018), http://time.com/5351648/2016-trump-tower-meeting-facts/.

326 Id.

327 Id.

328 Id.

329 Veronika Bondarenko \& Skye Gould, The 8 People Who Were in The Room When Donald Trump Jr. Met With the Russian Lawyer at Trump Tower to Get Dirt on Clinton, Bus. INSIDER (May 16, 2018), https://www.businessinsider.com/who-else-was-in-the-room-when-trump-jr-met-with-the-russian-lawyer2017-7. 
Magnitsky Act, who was working with Natalia Veselnitskaya ; ${ }^{330}$ Anatoli Samochornov who acted as a translator; ${ }^{331}$ and Irakly Kaveladze who was present "as a representative of Aras and Emin Agalarov, the wealthy Russians who first requested the meeting be arranged.”332

Initially, according to the Trump camp, the topic of conversation regarded "adoption of Russian children," 333 and the Magnitsky Act, a law that sanctions Russians who commit human rights abuses. ${ }^{334}$ According to those who attended the meeting, it only lasted about twenty to thirty minutes. ${ }^{335}$ The date of the meeting is significant since June marked the unofficial start of the general election, and after months of intense campaigning during the primaries, Hilary Clinton and Donald Trump turned their attention to one another. ${ }^{336}$ Although there is no evidence that the Trump campaign received any incriminating information about Clinton during the Trump Tower meeting, President Trump and those involved have had shifting responses regarding what took place during the meeting.

First, after the New York Times reported the Trump Tower meeting, Trump Jr. released a statement in response on July 8, 2017. The statement read:

It was a short introductory meeting. I asked Jared (Kushner) and Paul (Manafort) to stop by. We primarily discussed a program about the adoption of Russian children that was active and popular with American families years ago and was since ended by the Russian government, but it was not a campaign issue at the time and there was no follow up. I was asked to attend the meeting by an acquaintance, but was not told the name of the person I would be meeting with beforehand. ${ }^{337}$

Trump Jr. did not mention the Clintons nor answer questions as to why he thought it was necessary to invite Manafort and Kushner to the meeting. ${ }^{338}$ The following day, the Times reported that Trump Jr. had been promised incriminating information about Clinton prior to the meeting. ${ }^{339}$ After this, Trump Jr.'s explanation changed to say that while he had been offered information, the lawyer's statements had been "nonsense" and not meaningful. ${ }^{340}$ On July 10, Trump Jr. tweeted in response "Obviously I'm the first person on a campaign to ever take a meeting to hear

$330 I d$.

331 Id.

332 Id.

333 Dan Merica, Recreating June 9: A Very Consequential Day in the 2016 Campaign, CNN (July 12, 2017) https://www.cnn.com/2017/07/11/politics/trump-campaign-june-9/index.html.

334 Id.

$335 I d$.

$336 I d$.

337 John Kruzel, A Timeline of the Shifting Accounts of Trump Tower Meeting With Russian Lawyer, POLITIFACT (July 14, 2018), https://www.politifact.com/truth-o-meter/article/2017/jul/14/timeline-shifting-accounts-trump-tower-meeting-rus/.

338 Id.

339 Id.

340 Kruzel, supra note 337. 
info about an opponent. . . went nowhere but had to listen." ${ }^{341}$ He went on to tweet that there were no inconsistencies in his statements, just further clarification because the meeting ended up being about adoptions. ${ }^{342}$ As information kept surfacing, Trump Jr. published the emails between himself and Rob Goldstone, where it was confirmed that he tried to obtain information from the Russian lawyer. ${ }^{343}$ However, Trump Jr. maintained that "he believed the information on Clinton was merely a 'pretext for the meeting,' and that the adoption program and the Magnitsky Act constituted its true agenda." 344

Following these events, President Trump’s lawyer, Jay Sekulow, denied the President's involvement in Trump Jr.'s initial statements about the Trump Tower meeting. ${ }^{345}$ Sekulow stated that he "wasn't involved in the statement drafting at all, nor was the President." 346 Days later, on July 31, 2017, the Washington Post published an article exposing that President Trump had dictated the first statement that Trump Jr. released to the public. ${ }^{347}$ In response, Sekulow issued a simple statement "[a]part from being of no consequence, the characterizations are misinformed, inaccurate, and not pertinent." 348 The following day, on August 1, 2017, the White House Press Secretary, Sarah Sanders, issued another statement assuring the press that Trump Jr.'s statements were true. ${ }^{349}$ Furthermore, Sanders stated that apart from there been no inaccuracies in the statement, the President had "weighed in as any father would, based on the limited information that he had." 350 However, she did not offer any explanation for the varying accounts on what took place in Trump Tower, nor the reason behind the President's involvement in his son's statement. ${ }^{351}$

Additionally, on January 29, 2018, Sekulow and John M. Dowd, White House Counsel, sent a letter to Mueller where they contradict Sanders's version of the story. ${ }^{352}$ Instead of merely weighing in, the letter asserts that "the President dictated a short but accurate response to the New York Times article on behalf of his son, Donald Trump, Jr." 353 President Trump was not only involved in the decision to construct Trump Jr.’s allegedly misleading statement, but actually “dictated” the

341 Maya Rhodan, 'Had to Listen.' Donald Trump Jr. Defends Controversial Russia Meeting, Time (July 10, 2017), http://time.com/4851179/donald-trump-jr-russia-meeting-tweet/.

342 Kruzel, supra note 337.

343 Abigail Simon, supra note 325.

344 Id.

345 Id.

346 Id.

347 Ashley Parker et al., Trump Dictated Son's Misleading Statement on Meeting With Russian Lawyer, WASH. POST (July 31, 2017), https://www.washingtonpost.com/politics/trump-dictated-sons-misleading-statement-on-meeting-with-russian-lawyer/2017/07/31/04c94f96-73ae-11e7-8f39-eeb7d3a2d304_story.html?noredirect=on\&utm_term=.4b3a2993e9fa.

348 Abigail Simon, supra note 325.

349 Kevin Liptak, Trump 'Weighed in' on Son's Statement About Russia Meeting, White House Says,

CNN (Aug. 1, 2017), https://www.cnn.com/2017/08/01/politics/trump-russia-meeting-statement/index.html.

350 Id.

351 Id.

352 The Trump Lawyers' Confidential Memo to Mueller, Explained, N.Y. TIMES

(Jan. 29, 2018), https://www.nytimes.com/interactive/2018/06/02/us/politics/trump-legal-documents.html. 353 Id. 
statement. ${ }^{354}$ Consequently, Sekulow stated that he made a mistake denying the President's involvement in Trump Jr.'s statement. ${ }^{355}$ While stories continue to change, one thing is clear: the President's advisers worry that his direct involvement in his son's statement leave him vulnerable to allegations of a cover-up. ${ }^{356}$

Out of this controversy aroused an important question: was the President aware of the purpose of the meeting? The facts suggest he may have been aware of it. ${ }^{357}$ At first, the Trump administration and those involved in the meeting denied the President was aware of the reason behind the meeting. ${ }^{358}$ After the Trump Tower meeting was exposed in July 2017, President Trump told the New York Times “[n]o, I didn’t know anything about the meeting. . . must have been a very unimportant meeting, because I never even heard about it.” ${ }^{359}$ Furthermore, in September 2017, Trump Jr. testified before the Senate Judiciary Committee that he had not told his father about the email exchange because he did not want to bring information that is "unsubstantiated," and because the emails had nothing to do with the President. ${ }^{360}$ On a turn of events, almost a year later, President Donald Trump changed his story regarding the meeting. ${ }^{361}$

Despite President Trump's initial denial of any knowledge of the meeting, a few days after the first email, President Trump on June $7^{\text {th }}$ - the day the June $9^{\text {th }}$ Trump Tower meeting was finalized — stated "I am going to give a major speech on probably Monday of next week and we're going to be discussing all of the things that have taken place with the Clintons," President Trump told a crowd at a campaign rally. ${ }^{362}$ "I think you're going to find it very informative and very, very interesting." ${ }^{363}$ Subsequently, President Trump denied knowledge of the meeting when it was occurring, and included Trump Jr.'s initial statement that never mentioned the promise of dirt on Clinton. ${ }^{364}$

Then, in May 2018, it was revealed that back in January, 2018, President Trump's lawyers acknowledged to Mueller that not only did President Trump know about Trump Jr.'s initial statement, but he dictated that statement himself. ${ }^{365}$ In a letter to Mueller, President Trump's attorneys wrote:

354 Parker, supra note 347.

355 Eli Watkins, Trump Attorney Blames 'Bad Information' for His False Statements on Trump Tower Meeting, CNN (Aug. 5, 2018), https://www.cnn.com/2018/08/05/politics/jay-sekulow-trump-tower/index.html.

356 Parker, supra note 347.

357 See Jonathan Lemire, Trump Acknowledges Purpose of Meeting With Russian Lawyer, CHI. TRIBUNE (Aug. 6, 2018), http://www.chicagotribune.com/news/nationworld/politics/ct-trump-russian-lawyer-meeting-20180805-story.html.

358 Abigail Simon, supra note 325.

359 Id.

360 Id.

361 Lemire, supra note 357.

362 Natasha Bertrand, The Case for a Trump-Russia Conspiracy Just Got a Little Stronger, THE ATLANTIC (July 27, 2018), https://www.theatlantic.com/politics/archive/2018/07/trump-michael-cohen-trumptower-meeting/566303/.

$363 I d$.

364 Marshall Cohen, Trump Lawyers Say He 'Dictated' Statement on Trump Tower Meeting, Contradicting Past Denials, CNN (June 2, 2018), https://www.cnn.com/2018/06/02/politics/trump-lawyers-statementtrump-tower-russians/index.html.

365 Id. 
You have received all of the notes, communications and testimony indicating that the President dictated a short but accurate response to the New York Times article on behalf of his son, Donald Trump, Jr.... His son then followed up by making a full public disclosure regarding the meeting, including his public testimony that there was nothing to the meeting and certainly no evidence of collusion. ${ }^{366}$

After his initial denial, just days before this article goes to print, President Trump apparently changes his position again and tweets that the Trump Tower meeting was to get information on his opponent. ${ }^{367}$ On August 5, 2018, Trump tweets:

Fake News reporting, a complete fabrication, that I am concerned about the meeting my wonderful son, Donald, had in Trump Tower. This was a meeting to get information on an opponent, totally legal and done all the time in politics - and it went nowhere. I did not know about it! ${ }^{368}$

As news accounts concerning details about the Trump Tower meeting continue, the facts keep changing. ${ }^{369}$ Even in Trump's Sunday tweet, he claims the Trump Tower meeting was completely okay and at the same time seems astute enough to want to distance himself from it. ${ }^{370}$ Yet, subsequent accounts provide that former Trump legal team spokesperson, Mark Corallo, resigned because he believed he was witnessing obstruction of justice when President Trump dictated the letter concerning the Trump Tower meeting. ${ }^{371}$

In terms of potential obstruction of justice legal charges or recommendations addressed above, it appears the Trump legal team have some serious problems with the President's involvement with the Trump Tower meeting. When Trump's personal attorney, Michael Cohen, became subject of a federal investigation, Cohen evidently told Mueller's team President Trump knew of the purpose of the Trump Tower meeting before it occurred. ${ }^{372}$ As one news account recently observed, "If Donald Trump's former fixer is right - that the president knew his staff planned to meet with Russians-it'd be a dramatic development on at least two fronts of Robert Mueller's investigation." ${ }^{373}$ As one scholar recently opined: "[t]here are definite legal consequences to Cohen's statement [concerning the President's knowledge of the Trump

366 Id.

367 Emily Stewart, “This Was a Meeting to Get Information on an Opponent:” Trump Changes His Story on Russia Meeting, VOX (July 5, 2018), https://www.vox.com/policy-and-politics/2018/8/5/17653136/trump-tower-meeting-tweet-trump-jr.

368 Id.

369 Id.

370 Id.

371 Michael Kranz, Former Trump Legal Team Spokesman Reportedly Quit Because He Believed Statement on Trump Tower Meeting was Obstruction of Justice, BUS. InsIDER (Jan. 4, 2018), https://www.businessinsider.com/trumps-spokesman-quit-because-he-thought-air-force-one-meeting-was-obstruction-of-justice-2018-1.

372 Jim Sciutto, Cohen Claims Trump Knew in Advance of 2016 Trump Tower Meeting, CNN (July 27, 2018), https://www.cnn.com/2018/07/26/politics/michael-cohen-donald-trump-june-2016-meetingknowledge/index.html.

373 David A. Graham, Michael Cohen's Astonishing Claim About the Trump Tower Meeting, THE 
Tower meeting].” 374 Cornell Law Professor Jens David Ohlin observed, “[t]his reeks of a criminal conspiracy. It doesn't matter if nothing came of the meeting. If Trump knew about the meeting and was okay with it, Trump and those around him could be guilty of an inchoate conspiracy.” 375 Former federal prosecutor, Harry Sandick, observed, if Cohen's reported version is correct, "it would make it very hard for Trump to say there was no collusion,' he said. "There would also be a potential obstruction charge, because he tried to prevent prosecutors from knowing what happened." 376 Indeed, it is a violation of federal elections laws for anyone to solicit contributions from foreign nationals. ${ }^{377}$ The election laws make clear that the solicitation can include in-kind things of value. ${ }^{378}$ The federal election regulations provide a broad reading of contributions to include making "any contribution or donation of money or other thing of value, or making any expenditure, independent expenditure, or disbursement in connection with any federal, state or local election in the United States." 379

The Federal Election Campaign Act prohibits knowingly soliciting, accepting or receiving contributions or donations from foreign nationals. In this context, "knowingly" means that a person:

(1) Has actual knowledge that the funds solicited, accepted, or received are from a foreign national;

(2) Is aware of facts that would lead a reasonable person to believe that the funds solicited, accepted, or received are likely to be from a foreign national; or

(3) Is aware of facts that would lead a reasonable person to inquire whether the source of the funds solicited, accepted or received is a foreign national. ${ }^{380}$

If proven accurate, the facts above concerning the Trump Tower meeting should give the Trump legal team some very serious trouble. Both the assertions of Cohen and the President's own contemporaneous promise to provide an important speech concerning Hillary Clinton strongly suggests that the President did have at least some knowledge of the meeting and its purpose. Such knowledge, and the agreement to

ATLANTIC (July 27, 2018), https://www.theatlantic.com/politics/archive/2018/07/michael-cohen-trump-towermeeting/566225/.

374 Natasha Bertrand, The Case For a Trump-Russia Conspiracy Just Got a Little Stronger, THE ATLANTIC (July 27, 2018), https://www.theatlantic.com/politics/archive/2018/07/trump-michael-cohen-trumptower-meeting/566303/.

375 Id.

376 Chris Strohm et al., Trump and Son at Legal Risk If Found Lying About Russia Meeting, BLoomBERG (July 28, 2018), https://www.bloomberg.com/news/articles/2018-07-28/trump-and-son-at-legal-risk-iffound-lying-about-russia-meeting.

377 Myles Martin, Foreign Nationals, Fed. Elections Comm’N (June 23, 2017), https://www.fec.gov/updates/foreign-nationals/.

$378 I d$.

379 Id.

380 Id. 
go forward with said meeting may expose President Trump to criminal issues.

As examined above, pursuant to 18 U.S.C. § 1503, federal law prohibits conspiracy against obstruction justice. If Trump and his team had knowledge that his son and others were entering into a meeting in order to obtain "dirt" on then Democratic candidate Hillary Clinton, then President Trump was entering into a meeting soliciting something of value from a foreign national in violation of federal election laws, under 52 U.S.C. $\S 30121$ and generally, 11 CFR 110.20. ${ }^{381}$ His efforts to cover up the purpose, his knowledge of the purpose of the meeting demonstrates knowledge of the meeting's wrongful nature. The fact the Trump team planned on participating in the meeting, and did in fact participate in meeting, may demonstrate they conspired to obtain something otherwise forbidden by law; soliciting something of value from a foreign national. Their repeated subsequent efforts to cover up the purpose of the meeting not only highlights their knowledge, intent, and awareness of their conspiracy. Said knowledge may very well also rise to a classic obstruction of justice under $\S 1503$, though it is likely there will be great debate concerning the "pending proceeding” requirement under an obstruction charge as opposed to a conspiracy to obstruct charge. The irony is that we may never really know the full extent and scope of the Trump Tower meeting. We may never really know the truth behind the discussion of Trump and Flynn, or Comey. President Trump has consistently made contradictory statements that undermine his credibility.

\section{CONCLUSION}

The potential impeachment, and possibly even indictment, of Donald Trump and members of his administration for obstruction of justice has captured both the country and the world's attention. While references to terms like collusion and obstruction are routinely bantered about, few have explained the legal standard and consequences of these terms of art. In the end, an examination of federal law addressing the term collusion highlights the fact that while the word collusion is not listed as a wrong in any likely claim against the President, the term is well-defined in federal law. Ultimately, it is considered a factual analysis that can become the predicate acts to punish behavior in a host of legal settings. In a potential Trump impeachment, collusion, or facts considered to be collusive may very well provide the basis for one or more obstruction of justice claims or charges. Further, the federal offense of obstruction of justice provides an ample legal basis to find, if the facts so establish, that a president, including President Trump can obstruct justice, and may very well have obstructed justice. The catch-all provision of 18 U.S.C. $\S 1503$ is likely one of two primary provisions that may be used in any potential charges against Trump. Indeed, there may be at least three independent legal justifications under the obstruction statutes to conclude obstruction occurred in the Trump context, if once again the Special Prosecutor so establishes and the ultimate trier of fact so agrees. A brief overview of the leading alleged factual wrongs by President Trump under the federal obstruction statutes establish that if in fact these allegations are proven and accepted, they provide

381 See generally, Contributions and Donations by Foreign Nationals, 52 U.S.C. § 30121 (2002); see also Prohibition on Contributions, Donations, Expenditures, Independent Expenditures, and Disbursements by Foreign Nationals, 52 U.S.C. § 30121, 36 U.S.C. § 510, 11 C.F.R. § 110.20 (2014). 
the factual predicates for a finding of obstruction of justice under federal law. Finally, the question of whether a sitting president may face criminal charges should lead an ultimate arbiter of the issue to conclude a sitting president is in fact subject to criminal process. In the end, if Special Prosecutor Robert Mueller decides there is a factual basis for the claims of presidential wrongdoing, and a trier of fact so agrees, federal law on obstruction of justice provides ample basis for articles of impeachment, and possibly a federal indictment. 